\title{
A Framework for Sales and Operations Planning in Process Industries
}

\section{Sayeh Noroozi}

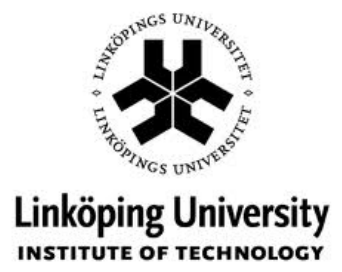

2014

Division of Production Economics Department of Management and Engineering Linköping University, SE-581 83 Linköping 
(C) Sayeh Noroozi, 2014

Linköping studies in science and technology, Thesis No. 1667

LiU-TEK-Lic 2014:100

ISBN: 978-91-7519-301-4

ISSN: 0280-7971

Printed by: LiU-Tryck, Linköping

Distributed by:

Linköping University

Department of Management and Engineering SE-581 83 Linköping, Sweden

Tel: +4613 281000, fax: +4613281873 
"Knowledge is love and light and vision." Helen Keller 



\begin{abstract}
This thesis studies Sales and Operations Planning (S\&OP) in process industries. S\&OP is a planning process which has a role of balancing demand and supply at an aggregate level. S\&OP has traditionally been considered as a generic process meaning that it is independent from the context of the industry in which it is implemented. Process industries do; however, have specific characteristics which affect their planning and control processes, including S\&OP. Therefore, the aim in this thesis is to reconcile these two contradictory stances and furthermore investigate how the specific properties in process industries should be included into an S\&OP framework. Such a differentiated framework aims to support process industries to design/implement their S\&OP process based on their unique requirements in relation to their markets, products and processes while it also takes into account the specific characteristics regarding the continuous production. Consequently, the process industries would realize the expected benefits from S\&OP process to a greater extent.
\end{abstract}

The study starts with a literature review on S\&OP in process industries in order to build the knowledge foundation for subsequent studies. The results show that the underlying difference between process industries and discrete industries is the object continuity which affects the selection of production processes including resources. Thus, process industries are often hybrids in the sense that their production processes include both continuous production, when the transformed object (material) is continuous, and discrete production when the object (material) turns into discrete products after the discretization point. In other words, process industries deploy both continuous production and discrete production while discrete industries use only discrete production. The specific characteristics of process industries are actually related to the continuous production part and influence the planning processes as well. As the result of this study, the continuous production characteristics that can affect the S\&OP process are identified.

In the continuation of the thesis and in order to provide a typology for planning and control purposes, the object type (continuous and discrete) is combined with two other dimensions i.e. mode type (onetime, intermittent and continuous) and driver type (customer order driven and forecast driven) into a planning and control typology. The mode type addresses the repetitivity of the flow and the driver type takes into account the trigger of the flow. Each dimension has a transition point - i.e. the discretization point for the object type, mode interface point for the mode type and customer order decoupling point for the driver type and represents a hybrid situation since different production environments are required before and after each transition point. The typology aims to illustrate how each dimension affects the planning and control issues as well as how the dimensions are interrelated and how this combination influence the managerial decisions. The typology integrates the concepts from both process industries and discrete industries and thus, is applicable for both.

Thereafter the typology is applied to the S\&OP process and an integrated framework is suggested based on the three dimensions with specific focus on process industries. In this framework, the effects of hybridities within each dimension and cross-hybridities between the dimensions on the S\&OP process are also considered. The importance of hybridities and cross-hybridities lies in the fact that the planning of the hybrid systems is a complex task due to the varying managerial decisions before and after the transition points. Finally, 
implementation steps for the suggested S\&OP framework are outlined for the process industries in order to position themselves in the framework, identify the implementing procedures, and obtain potential benefits based on the differentiated S\&OP process. 


\section{Foreword}

Working as a PhD student for me has been like a journey, with its happy and sad moments, just the way the life is. But happiness and sadness are like two sides of a coin, a person cannot feel one without experiencing the other. One thing is for sure: you need good friends to share all these moments with and I was blessed with many to whom I am always grateful.

First of all, I would like to thank my supervisors Professor Joakim Wikner and Professor Ou Tang for fruitful discussions and wise guidance during this time. Joakim has also been the coauthor for all the papers and I like to thank him for his support, kindness and great sense of humor which all helped me to go on, even through tough times, with a smiling face and a light heart!

I would also like to thank all my dear colleagues and friends at the division of Production Economics, IEI and Linköping University, for creating a warm welcoming environment for scientific discussions as well as pleasant leisure time together. I want to especially mention Christina Maack who has always been there for me as a friend, a sister and a mentor as well as Kristina Karlsson who can only be resembled to the Sun; kind, warm and shining.

In the end, I would like to thank the dearest people in my life; my parents, my brother and his family. Mom and Dad, I would not be the person who I am now if not because of you, and your endless support and presence, even though we were miles away. Thank you for showing me the right way and real values in life, believing and trusting in me and helping me all this time.

A lovely spring day in Esfahan,

April 2014 

Table of Contents

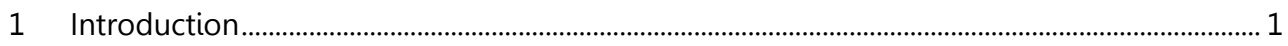

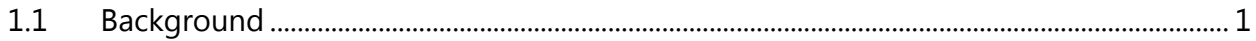

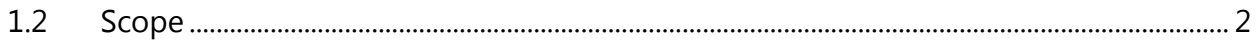

1.3 Purpose and research objectives ......................................................................................... 2

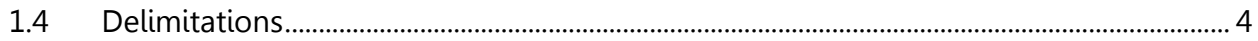

1.5 Thesis outline

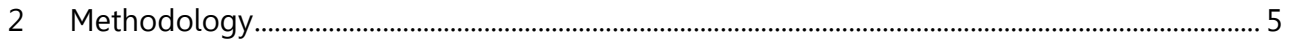

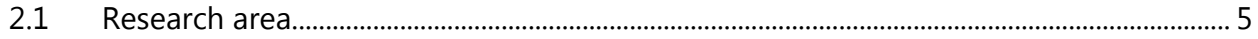

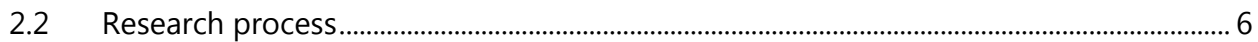

2.3 Research strategy ............................................................................................................... 7

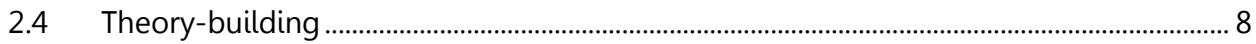

2.4.1 Theory-building research................................................................................................... 8

2.4.2 Conceptual research methodologies ........................................................................... 9

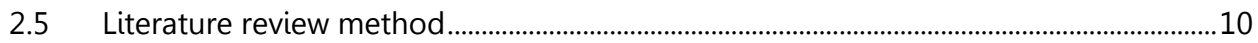

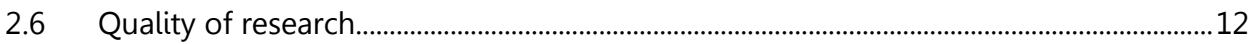

2.6.1 Operations management research in process industries ............................................. 12

2.6.2 "Good" theory......................................................................................................................... 12

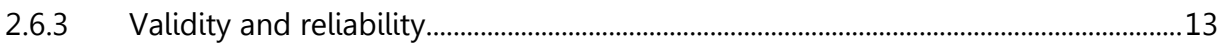

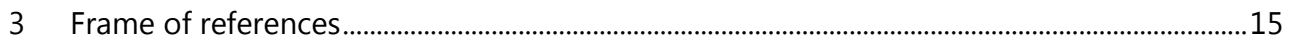

3.1 Process industries ...................................................................................................................... 15

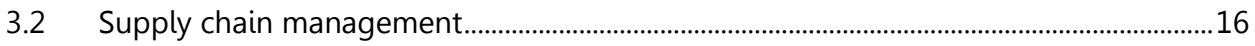

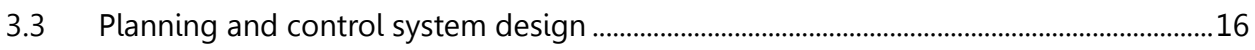

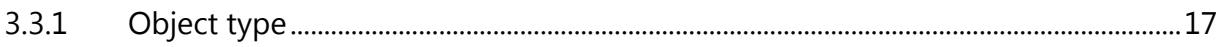

3.3.2 Mode type ................................................................................................................. 17

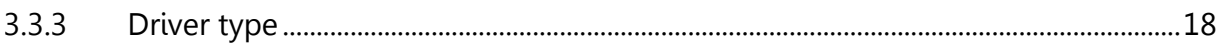

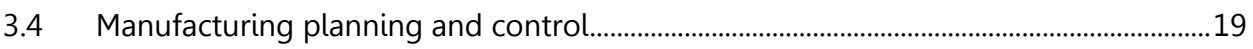

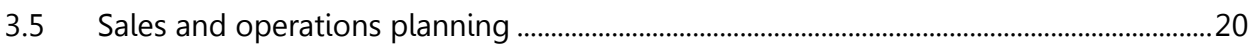

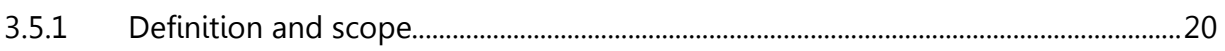

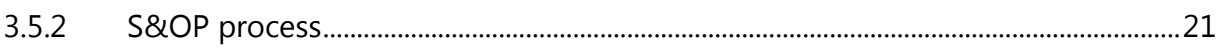

3.5.3 Results and metrics ................................................................................................... 22

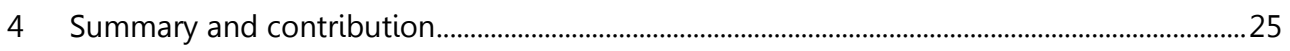

4.1 Paper 1: Sales and operations planning in the process industry ......................................25

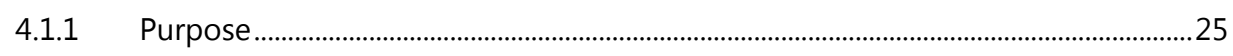

4.1.2 Contribution of the paper................................................................................................ 25 
4.2 Paper 2: Typology for planning and control - Combining object type, mode type, and driver type

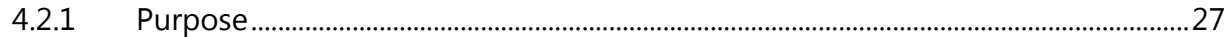

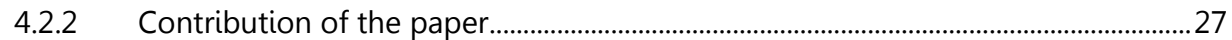

4.3 Paper 3: Sales and operations planning in process industries based on types of object, mode and driver: An implementation guide .....................................................................28

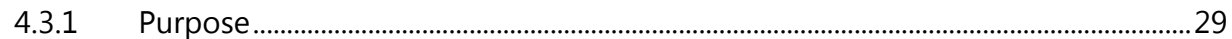

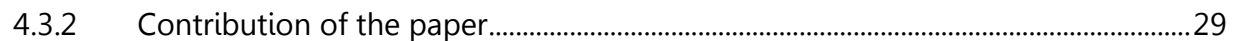

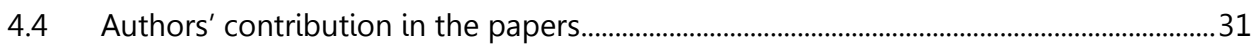

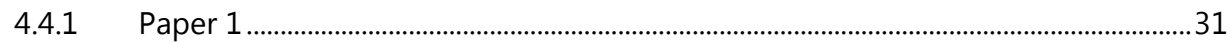

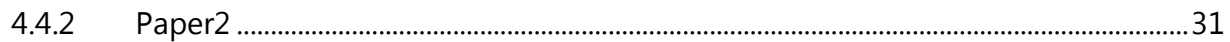

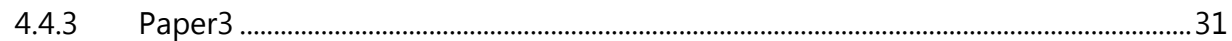

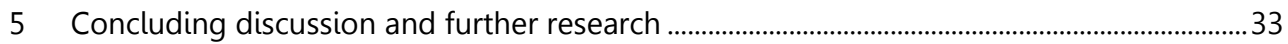

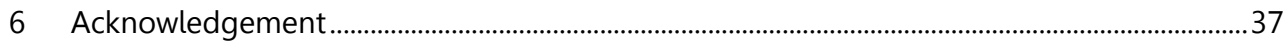

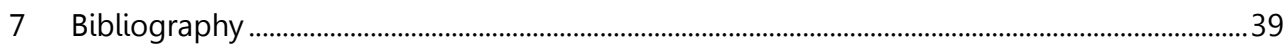

Papers

Paper1. Sales and operations planning in the process industry

Paper2. Typology for planning and control - Combining object type, mode type, and driver type

Paper3. Sales and operations planning in process industries based on types of object, mode and driver: An implementation guide 


\section{List of figures}

Figure 1: Process Industry vs. discrete industry .................................................................................... 2

Figure 2: The relation between the research objectives ........................................................................ 4

Figure 3: Main areas in research on process industries (Van Donk \& Fransoo, 2006) .................... 6

Figure 4: Research process....................................................................................................................... 7

Figure 5: The information flow between the papers........................................................................... 7

Figure 6: Theory-building types of research (Wacker, 1998, p. 378) .................................................. 9

Figure 7: Conceptual research methodologies (Meredith, 1993, p. 7) ..............................................10

Figure 8: Main steps of a systematic review (Tranfield, et al., 2003, p. 214)....................................11

Figure 9: Properties of "good" theory (Wacker, 2008, p. 8).................................................................13

Figure 10: Driver type and customer order decoupling point (CODP) based on Wikner (2014)

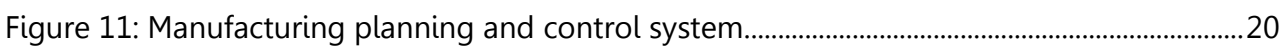

Figure 12: S\&OP process (Wallace, 1999) ..........................................................................................2 22

Figure 13: Sales and operations planning in the supply chain context ...........................................26

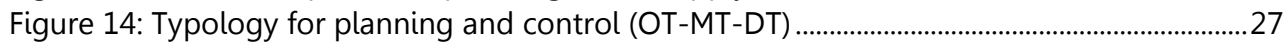

Figure 15: The four identified cross-hybridities......................................................................................28

Figure 16: S\&OP framework implementation steps............................................................................. 30 



\section{List of tables}

Table 1: Generic, DO and CO specific issues affecting sales and operations planning ..............26 Table 2: Differentiating characteristics between process industry and discrete manufacturing industry

Table 3: Important issues in S\&OP process with regard to the eight building blocks................29

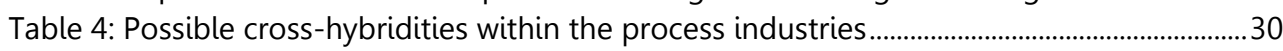

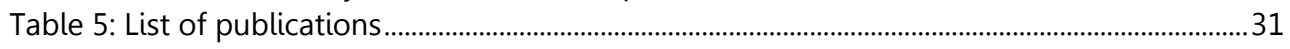

Table 6: The relation between the thesis, research objectives and papers .....................................33 



\section{List of Acronyms}

Sales and Operations Planning S\&OP

Supply Chain Management SCM

Discrete Manufacturing Industry DI

Manufacturing Planning and Control MPC

Object Type OT
OT

Mode Type MT

$\begin{array}{ll}\text { Driver Type } & \text { DT }\end{array}$

Continuous Object $\quad \mathrm{CO}$

Discrete Object DO

Onetime Mode OM

Intermittent Mode IM

Continuous Mode CM

Customer Order Driven or Commitment $\quad C D$

Driven

Forecast Driven $\quad$ FD

Speculation Driven SD

Hybrid Driven HD

Discretization Point DiPo

Customer Order Decoupling Point CODP

Process Industry Center $\quad$ PIC

$\begin{array}{ll}\text { Research Objective } & \text { RO }\end{array}$

Key Performance Indicator KPI 



\section{Introduction}

This thesis addresses Sales and Operations Planning (S\&OP) in process industries. Process industries have specific properties, such as high-volume products and process flow production, which affect their planning processes (Dennis \& Meredith, 2000a). Nevertheless, S\&OP has generally been considered as a generic process (Proud, 1999) indicating that $\mathrm{S} \& O P$ is not merely a mathematical optimization model but a planning process consisting of successive steps (Wallace \& Stahl, 2008). Generic, in this context, means that the standard $\mathrm{S} \& \mathrm{OP}$ process is not dependent on industries' specific characteristics. It is therefore of interest to reconcile these two contradictory stances and investigate whether process industries' characteristics affect the S\&OP process and how these characteristics should be included into a differentiated S\&OP process.

\subsection{Background}

This thesis has been performed within the Process Industry Centre (PIC) which is funded by the Swedish Foundation for Strategic Research (SSF). Process industries - such as food, chemical and steel industries - play an important role in Sweden's economy by accounting for 30\% of Sweden's total export and $60 \%$ of the net export (IVA, 2006). In order to strengthen this sector, new applicable knowledge in the areas of competitiveness, flexibility, control, sustainability and accessibility is required (Stiftelsen för Strategisk Forskning, 2007), and it was in this spirit that PIC was established.

The concept of manufacturing planning and control for process industries has been under focus during the last 20 years due to the interest in flexible processing, responsiveness to global demand and continuation of business competitiveness and growth (Kopanos, et al., 2011). Modern companies nowadays involve multi-product multi-location facilities and consequently, the supply chains of these companies include a network of geographically dispersed manufacturing facilities and distribution centers (Shah \& lerapetritou, 2012). This puts more emphasis on planning processes and the integration of supply chains to ensure the success in the competitive market (Papageorgiou, 2009) (Oliva \& Watson, 2011). Identifying the right manufacturing planning process is a critical task which among others depends on the manufacturing environment of a company (Dennis \& Meredith, 2000a). Process industries though still lag behind the discrete manufacturing industries (DIs) in the implementation of manufacturing planning processes which match their specific characteristics and requirements (Dennis \& Meredith, 2000b). This is specifically noticeable at the strategic/tactical planning level (Finch \& Cox, 1988) (Proud, 1999) including S\&OP.

$\mathrm{S} \& O P$ is defined as "a process to develop tactical plans that provides management the ability to strategically direct its businesses to achieve competitive advantage on a continuous basis by integrating customer-focused marketing plans for new and existing products with the management of the supply chain" (Blackstone Jr., 2010). The main goal of this process is to balance demand and supply at an aggregate level (Wallace \& Stahl, 2008) and this is achieved through integration of different functions inside and outside the company within the scope of the supply chain (Affonso, et al., 2008) (Oliva \& Watson, 2011).

S\&OP has, to a large extent, been developed in industries (Grimson \& Pyke, 2007) and despite the growth of academic literature about it during recent years, the gaps between industrial needs and academic research still exist. The literature on this subject usually does 
not specify the context within which the S\&OP process is implemented or is directly related to DIs, i.e. companies that produce distinct items such as automobiles, appliances, or computers (Blackstone Jr., 2010). Accordingly, S\&OP has mainly been considered as a onesize-fits-all process (Proud, 1999) and independent from the specific characteristics of any particular industry. Process industries though are different from DIs and these differences can affect S\&OP in these companies. In line with Abdulmalek, et al. (2006), the difference between process industries and DIs can be explained through the fact that process industries are actually hybrids. This means that there is a point in their production process where continuous production turns into discrete production, see Figure 1. This point is referred to as "discretization point" (Pool, et al., 2011). Hence, process industries deploy both continuous production and discrete production while discrete industries use only discrete production. Thus, cell 3 in Figure 1 is empty since Dls do not deploy continuous production. It should be noted that in APICS dictionary, "continuous production" is used in relation to the continuous flow of material but in this thesis, this term is used instead of the term "process flow production" to represent an analogy to discrete production. APICS defines process flow production as "a production approach with minimal interruptions in the actual processing in any one production run or between production runs of similar products". The term "process flow production" thus is more focused on the continuity of materials than just the flow.

\section{Continuous production Discrete production}

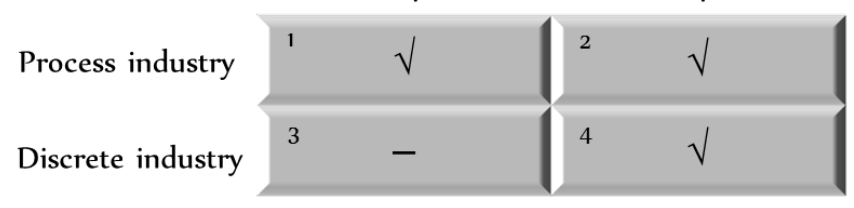

Figure 1: Process Industry vs. discrete industry

The generic S\&OP process is mainly focused on cell 4 in Figure 1 and can also be extended to cell 2 but cell 1 deals with a different production environment. The question therefore is whether or not the process industries can realize more benefits by designing/modifying their S\&OP process based on their specific characteristics and requirements related to the continuous production.

\subsection{Scope}

The scope of this thesis covers operations management in process industries and S\&OP and the integration of these topics together. It is worth mentioning that on one hand, S\&OP in this thesis is considered as a subset of supply chain planning but on the other hand, S\&OP can be used as a tool for the integration of supply chains since different supply chain partners, e.g. customers and suppliers, can be involved in different steps of the S\&OP process.

\subsection{Purpose and research objectives}

The purpose of this thesis is to develop a framework for S\&OP in process industries.

In order to cover this purpose, two sub-purposes have been defined. First, the aim is to scrutinize process industries' characteristics, especially the ones related to continuous production which might affect S\&OP process. Second, the goal is to identify the key 
dimensions influencing the design of a planning system for both process production and discrete production. The results of two sub-purposes are then combined in an integrated S\&OP framework which considers both continuous production and discrete production. The aim with this framework is to cover the underlying terms in this context, their definitions and connections and the prediction of the framework's outcomes. The framework thus is based on both the identified key dimensions and the process industries' characteristics.

In order to cover the purpose of the thesis, three research objectives (ROs) are defined. Each research objective is fulfilled through a separate study; however, they are logically connected to each other and the succeeding research objectives are built-up on the results of the preceding ones.

S\&OP has so far been considered as a generic process i.e. independent of the context of the industry within which it is implemented. Thus the first step in this thesis is to examine whether process industries' properties influence the design/ implementation of the S\&OP process.

R01. Identify the key characteristics of S\&OP with regard to the operations properties of the process industry and the extent to which the S\&OP process has been implemented in process industries.

RO1 is fulfilled through a systematic literature review.

As mentioned earlier, process industries are hybrids of continuous production and discrete production. The discretization point between these two types of production can be used as a point-of-reference in the manufacturing planning and control of Pls as defined in $\mathrm{RO} 2$ and RO3.

R02. Based on the process industries' properties, identify the key dimensions in the design of planning and control systems for process industries including both continuous production and discrete production.

R03. Develop a framework for S\&OP with focus on the differentiating properties of the process industries, specifically in relation to continuous production and based on the identified key dimensions.

$\mathrm{RO} 2$ and RO3 are fulfilled through logical reasoning and theory-building methods.

The relations between the ROs are shown in Figure 2. RO1 has inputs to both RO2 and RO3 which is related to the key properties of process industries as well as their effect on S\&OP. RO3, which provides the final result of this thesis i.e. the S\&OP framework, is based on the results of both RO1 and RO2. Each paper (P1, P2 and P3) covers one of the ROs. 
Key properties of process industries, S\&OP in process industries

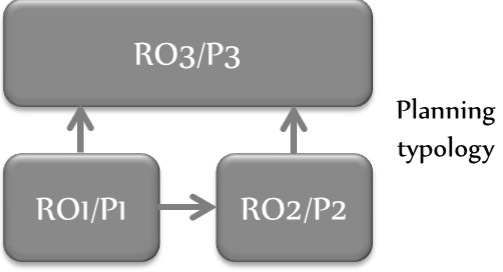

Key properties of process industries

Figure 2: The relation between the research objectives

\subsection{Delimitations}

In this thesis, S\&OP process, in general terms, is under focus. Even though different steps of the S\&OP process are briefly discussed, this work does not include the details of e.g. demand planning, forecasting methods or supply planning. In addition, the suggested framework in this thesis is mainly based on secondary data, i.e. only the empirical results from the literature are used and that the framework has not been implemented in process industries yet. Thus the suggested framework is general, meaning that it can be used in different contexts e.g. in companies with global S\&OP; however, the framework does not provide any details for any specific context.

\subsection{Thesis outline}

The rest of the thesis is as follow. It starts with the methodology chapter describing the research process and the methods used to conduct the research. It then continues with frame of references to provide a background of the applied concepts and ends with the summary of the three presented papers and contribution of the thesis, and the conclusion and further research ideas. The three papers are attached in the appendix. 


\section{Methodology}

In this chapter, the applied methods in this thesis are presented. The chapter starts with an overview about the research area, continues with the specific research process used in this study and ends with a discussion about the research quality criteria. Each sub-chapter begins with a general description and then demonstrates the application of the methods in the thesis.

\subsection{Research area}

This thesis has been written in the field of Operations Management (OM) and in relation to process industries. APICS dictionary defines OM as "a field of study that focuses on the effective planning, scheduling, use, and control of a manufacturing or service organization through the study of concepts from design engineering, industrial engineering, management information systems, quality management, production management, inventory management, accounting, and other functions as they affect the operation" (Blackstone Jr., 2010). This research is classified as part of OM due to the fact that even though S\&OP can be used as a tool for the integration of supply chain, it is still more focused on the flow of material and their transformation in relation to e.g. a focal company and its main suppliers and customers. The other extreme of this view, which is more focused on the field of supply chain management, is to emphasize the cooperation between different actors in the supply chain and not focus much on the manufacturing activities of each of them.

In the editorial of the special issue of Journal of Operations Management about process industries, Van Donk \& Fransoo (2006) have introduced three building blocks in relation to the operations management research in process industries, see Figure 3. They believe that more emphasis should be placed on the links between these blocks meaning that the research in this field should take the specific characteristics of process industries into account in the manufacturing planning and control (MPC) models and to combine them with empirical work in order to develop the differentiated applicable models for process industries.

The current research investigates the S\&OP process as part of the "manufacturing planning and control" / "supply chain planning" models in the context of process industries, i.e. identifies specific properties of process industries affecting S\&OP and suggests a differentiated S\&OP model based on process industries' differentiating characteristics and thus covers two of the building blocks represented in Figure 3 namely process industries' properties and MPC models. 


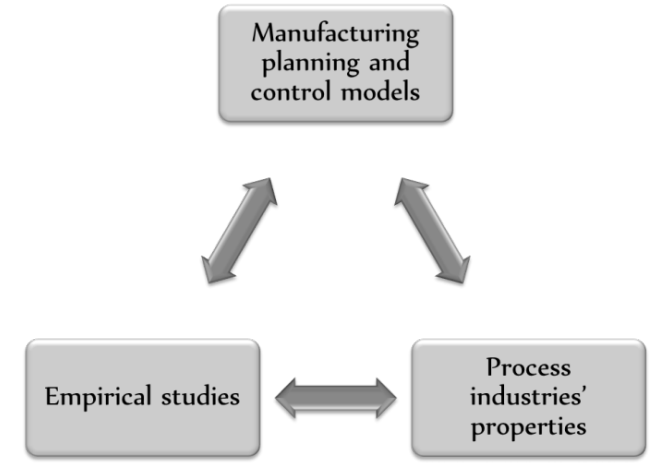

Figure 3: Main areas in research on process industries (Van Donk \& Fransoo, 2006)

Next part illustrates the specific research process designed for this thesis.

\subsection{Research process}

This thesis has been performed within the Process Industry Center (PIC) which is a research and competence development center funded by the Swedish Foundation for Strategic Research (SSF). PIC has two project centers: PIC-LI at Linköping University which is focused on operations management and PIC-LU at Lund University which works on automatic control issues. These two centers also cooperate in a joint research project called PIC-opic. This thesis is part of the PIC-opic project in PIC at Linköping University.

This work has started with a pre-study of the whole manufacturing planning and control system of a food processing company. The results of the pre-study highlighted the importance of S\&OP due to its direct relation to companies' strategic planning and business goals and the fact that it connects and aligns the strategic and operational plans of a company by imposing frameworks and constraints on the operational plans. Meanwhile, a brief literature review was performed in order to find a modified S\&OP model for process industries but the results showed that such a model has not been developed yet. The conclusion then was that the topic would be of interest for both academia and practitioners. Accordingly, the purpose and the research objectives have been defined, see 1.3.

Figure 4 illustrates the research process. The right arrow callouts show the milestones of the thesis, the round diagonal corner rectangles display the results/concepts, the rounded rectangles represent the titles of papers related to each $\mathrm{RO}$, the dashed lines point out the scope and finally the arrow at the bottom represents the timeline of the licentiate project. The scope changes between supply chain management (SCM) and S\&OP when S\&OP can be considered as a subset of SCM. It should also be noted that S\&OP can be used as a tool to integrate different parts of the supply chain. Despite the fact that S\&OP and process industries have mainly been studied separately in the literature, in this thesis they are combined together from the very beginning. Each research objective is answered in a separate paper. 


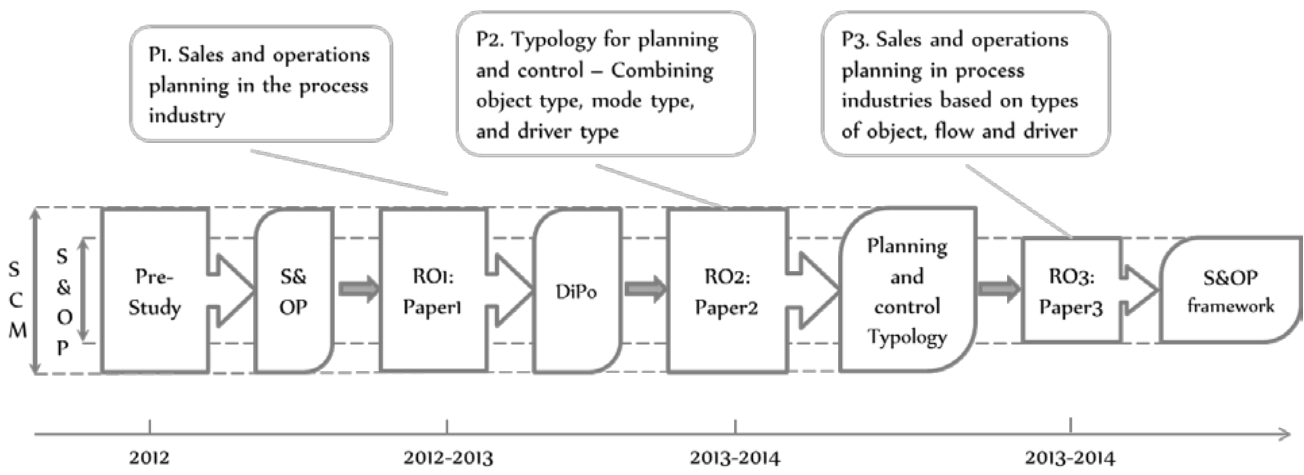

Figure 4: Research process

As shown in Figure 4, after the pre-study a literature review is conducted in Paper1 (P1) in order to provide a firm foundation for the future research and to identify the gaps in the field. As the result, the discretization point (DiPo) and the S\&OP characteristics with regard to the specific properties of process industries (mainly in relation to the continuous production) have been noticed. DiPo is related to the physical properties of the material, here referred to as object type, which should be transformed in the production process. The concept of DiPo is then combined with two other important aspects of planning system design, here referred to as mode type and driver type. It is due to the fact that from the planning perspective, the repetitivity of material flow and the trigger of the flow are crucial. These planning aspects build the core of the suggested planning typology in Paper2 (P2). Since the focus of this thesis is on S\&OP, this typology is then applied to S\&OP in Paper3 (P3) with focus on process industries' characteristics (mainly related to the continuous production) which is provided from P1.

In general, DiPo is the core which keeps the whole content connected to the process industry. The information flow between the papers is presented in Figure 5. As it can be seen, P1\&P2 provide the foundations for P3.

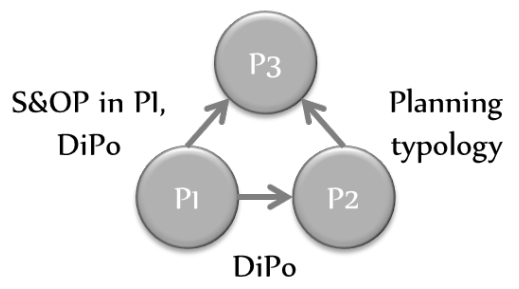

Figure 5: The information flow between the papers

In the following parts, the methods uses to conduct this research are presented.

\subsection{Research strategy}

There are different relations between theory and research in terms of building arguments including induction, deduction and abduction (Bryman \& Bell, 2007) (Karlsson, 2009). The deductive approach suggests hypotheses based on present rules and theories and examine them through the empirical observations to conclude if they are verified (ibid.). The inductive 
approach, on the other hand, starts with the empirical observations and tries to build the rules/theories (ibid.). Abductive approach is a combination of induction and deduction and enables the researcher to move back and forth between empirical observations and existing theories in order to suggest new theories (Kovács \& Spens, 2005). The aim of all these approaches is to build theory and create knowledge.

Another classification of research strategy is focused on qualitative and quantitative methods (Bryman \& Bell, 2007). Qualitative approach is concerned with interpretation, perception and interaction in data collection and analysis (Karlsson, 2009). Quantitative approach, on the other hand, is mainly focused on mathematical and statistical tools in gathering data and analyzing the results (ibid.). Traditionally, qualitative and quantitative are related to inductive and deductive approaches respectively; however, this distinction is not considered as restrict and the qualitative approach has been used in deductive research as well (Bryman \& Bell, 2007).

This thesis is of qualitative nature and is mainly focused on definitions, interpretation and interaction between different terms and concepts. In addition, this work has its roots in previous research and is based on the existing theories in the literature including production planning, see e.g. Waller (1999) and decoupling point theory, see e.g. Hoekstra \& Romme (1992). Finally, conclusions are mainly drawn from logical reasoning which implies the deductive research approach.

\subsection{Theory-building}

Within its qualitative scope, the purpose of this thesis is to suggest an integrated S\&OP framework for process industries based on their specific properties in relation to the continuous production. Considering the two general objectives of research, i.e. theorybuilding and fact-finding, this thesis is categorized as the theory-building research. This method has been used in P2 and P3 in relation to RO2 and RO3. It should be noted that this thesis does not claim to constitute a theory but is of nature of theory-building versus factfinding, in line with Wacker (1998, p. 371).

\subsubsection{Theory-building research}

Theory is defined as "an explained set of conceptual relationships" (Wacker, 2008, p. 7) and "a coherent group of interrelated concepts and propositions used as principles of explanation and understanding" (Meredith, 1993, p. 7). For more information about what theory is/not, the readers are referred to (Weick, 1995).

A theory should include four parts (Wacker, 1998) (Meredith, 2001):

i. Description/definition: definition of terms which is related to who and what research questions;

ii. Domain: this aspect is related to when and where research questions;

iii. Explanation/understanding of relationships: the relationships between the terms which is related to how and why research questions;

iv. Predictions: this is related to what would, should, could happen as the result of the theory.

Meredith (2001) suggests that a theory-building process should have three phases: description and explanation of a phenomenon, building conceptual models, and validation 
and verification of the models. This iterative process continues until the conceptual models get refined and turn into theories. Different types of theory-building research are shown in Figure 6 . The methods being used in this thesis are highlighted in the figures in this chapter.

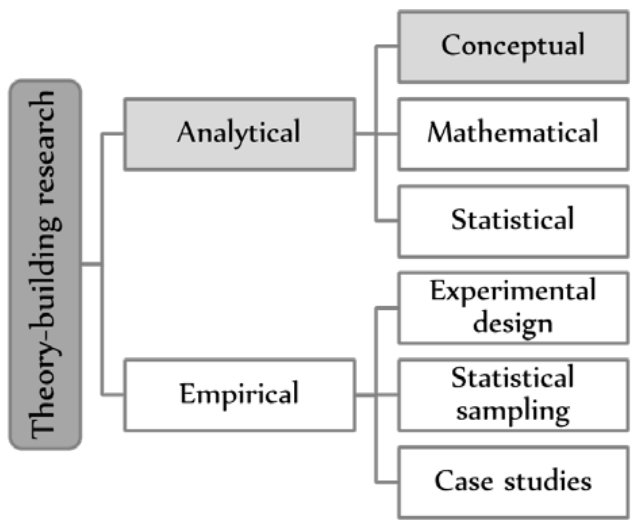

Figure 6: Theory-building types of research (Wacker, 1998, p. 378)

Based on this categorization, this thesis is located in the analytical conceptual box, in line with Wacker (1998), since it is based on deductive research strategy and aims to provide new insights into the field of production planning in general and S\&OP in the process industries in particular through logical reasoning. Regarding the four parts of the theory, in this thesis research objectives are defined instead of research questions. The objectives still cover the same criteria about what, who, when, where, how and why, only with different phrasing. This is due to the fact that most of the methodology literature is based on research questions (Yin, 2009) which are more suitable for empirical studies than analytical conceptual ones. The conceptual research methods are further explained in the following part.

\subsubsection{Conceptual research methodologies}

Meredith (1993, pp. 7-8) has introduced seven methodologies for a conceptual research ranked in explanatory power as illustrated in Figure 7.

The first three i.e. conceptual description, taxonomies and typologies, and philosophical conceptualization are the most basic in the hierarchy regarding the explanatory power (Meredith, 1993). The second three i.e. conceptual induction, conceptual deduction and conceptual systems are a collection of several interrelated concepts and try to provide explanation and understanding. The last one i.e. meta-framework is the final stage where theories are built (ibid.). 


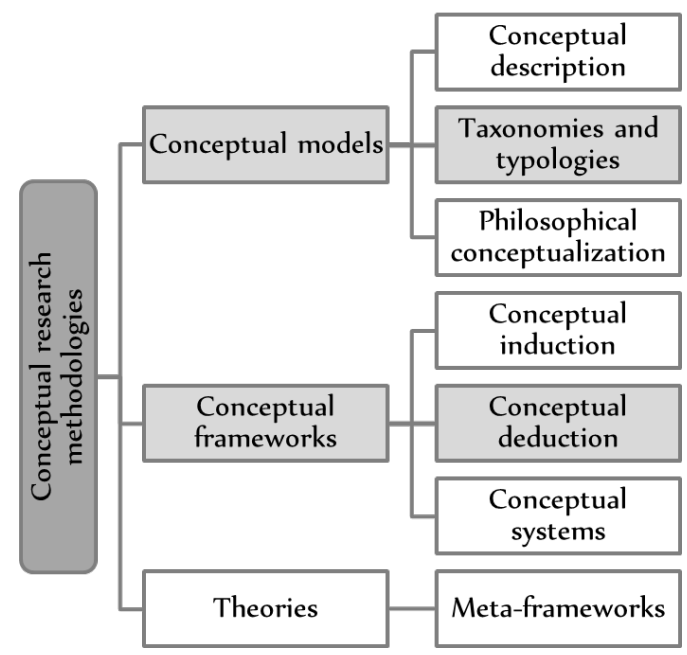

Figure 7: Conceptual research methodologies (Meredith, 1993, p. 7)

The conceptual research methodologies used in this thesis are taxonomies and typologies in relation to RO2 and conceptual deduction for RO3. Based on definition, taxonomies are "listings of items along a continuous scale" (Meredith, 1993, p. 8). Typologies then include two or more taxonomies on different dimensions (Meredith, 1993). The result of RO2 has been a typology for production planning including three dimensions of object type, mode type and driver type. Conceptual deduction, on the other hand, suggests a framework and provides detailed predictions which can be used for comparison with reality. It should also provide managerial insights and guidelines (ibid.). It should be noted that the relations between different concepts and prediction are based on logical reasoning and deduction (ibid.). The result of $\mathrm{RO} 3$ has been a conceptual deduction since it provides a conceptual framework of several concepts (i.e. object type, mode type and driver type as well as S\&OP) and the relationships between them. It also includes managerial insights on the implementation of the framework in practice.

\subsection{Literature review method}

Literature review is a fundamental part in all types of research (Croom, 2009). In conceptual research methodologies, literature review is a common data collection method since one of the aims of conceptual analytical models is to provide new insights into the conventional problems through logical reasoning (Wacker, 1998). Literature reviews provide a foundation for the future research and highlight the gaps in the body of literature (Croom, 2009). The main steps of a systematic review are shown in Figure 8.

Literature review is used in this thesis and all the papers to provide a robust foundation for the research. The formal systematic literature review has been used in P1 and the results of this paper then have been used in P2 and P3. Less formal literature reviews have also been performed in order to gather additional information related to P2 and P3. 


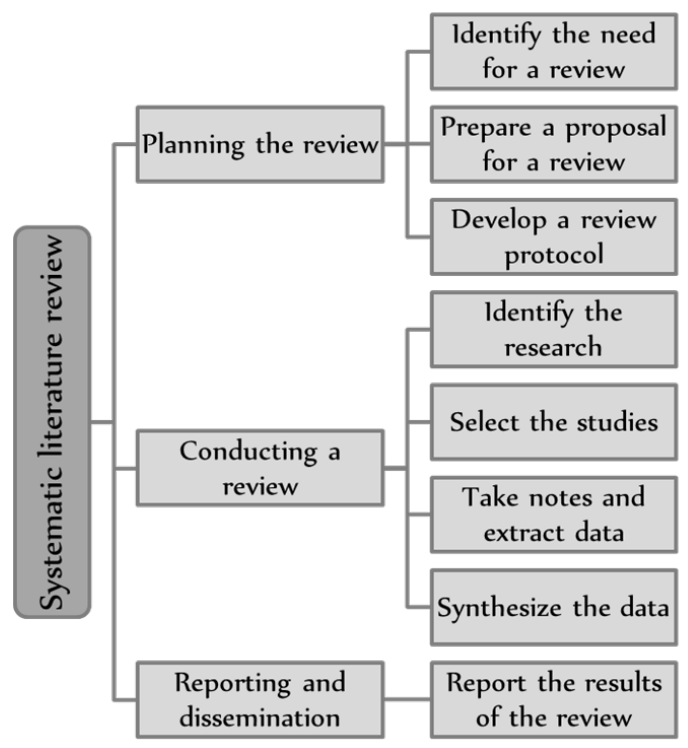

Figure 8: Main steps of a systematic review (Tranfield, et al., 2003, p. 214)

As mentioned earlier, the systematic literature review was the one and only method in relation to RO1 and P1. The synthesizing process used is "meta-ethnography" in which a researcher first defines a synthesis and then compares different studies to each other as well as to the synthesis in order to create value for the readers (Bryman \& Bell, 2007, p. 102). Tranfield et al. (2003, p. 218) suggest three synthesizing methods in relation to metaethnography: "refutational synthesis which can be used when reports give conflicting representations of the same phenomenon, reciprocal synthesis which can be used when reports address similar issues, and lines of argument synthesis which can be used if different reports examine different aspects of the same phenomenon". In this thesis and in relation to $\mathrm{RO} 1$, the reciprocal synthesis has been used since the reviewed studies were representing similar issues namely S\&OP.

The search for the papers has been done in databases which contain a large body of literature being published in areas related to operations management/research and industrial studies including peer-reviewed full-text articles such as ScienceDirect, Emerald and EBSCO. Where appropriate, the reference lists of the articles have been used to dig into specific areas (Croom, 2009). As suggested by Rowley \& Slack (2004) and in order to identify the recent developments in the field, articles from professional and business journals have been reviewed as well, such as Supply chain management review, Supply chain quarterly and APICS magazine. Business journals provide articles from the authors who might not publish in scientific journals but still provide different views about the companies' problems/achievements. These three journals have been chosen based on other researchers' recommendations. Even though the professional journals are used here, the core of this thesis is still based on the scientific articles. 


\subsection{Quality of research}

In this part, the quality of research is discussed from three perspectives: operations management research in process industries, "good" theory, and research validity and reliability. Since this research is done in the field of operations management and in relation to process industries, it is of interest to evaluate how it fulfills the needs and fills the gaps in this field. In addition, since theory-building method has been applied, the quality of the suggested typology and framework are evaluated based on the "good" theory criteria. Finally, due to the fact that this research is of qualitative nature, the reliability and validity aspects are discussed.

\subsubsection{Operations management research in process industries}

As mentioned in 2.1, Van Donk \& Fransoo (2006) suggest that the operations management research in process industries should include three building blocks: manufacturing planning and control/supply chain management models, process industries properties and empirical studies where the focus should be on the links between these blocks. Thus, they suggest that a good research in this field should cover at least two of these building blocks.

The current research investigates S\&OP process in the context of process industries, i.e. identifies specific properties of process industries affecting S\&OP and suggests a differentiated S\&OP model based on process industries' specific characteristics in relation to the continuous production. Thus, it covers two of the building blocks namely process industries' properties and MPC models. By integrating these two concepts i.e. S\&OP and process industries into a differentiated S\&OP model, this work also emphasizes on the link between these two blocks.

\subsection{2 "Good" theory}

Wacker (2008, p. 13) defines a "good" theory as "a fully explained set of conceptual relationships used for empirical investigations". As mentioned in 2.4.1, any theory should cover four parts: definition, domain, relationships and predictions. A "good" theory though should fulfill several additional properties as illustrated in Figure 9.

In general terms, a "good" theory should be differentiated and superior to other existing theories, applicable to broad areas, fertile to generate new hypotheses, have few assumptions, and be refutable (Wacker, 2004). For more information about these properties readers are referred to Wacker $(1998,2004,2008)$. As mentioned earlier, the author of this thesis does not claim to build a theory and the S\&OP framework has not been implemented in the industries yet; therefore, only some of these properties are applicable in this work.

The earlier studies about S\&OP in process industries are to a large extent quantitative, limited to specific type of industry (e.g. chemicals, food) and even case-specific. Thus, the lack of conceptual models and theories applicable to all process industries is evident. The typology and the framework suggested in this thesis are unique in the way that they combine different concepts related to process industries (mainly in relation to the continuous production) and DIs (discrete production) in an integrated model and yet, emphasize on the differentiating characteristics of each type of industry. Thus, these conceptual models fulfil the uniqueness and conservatism properties. 


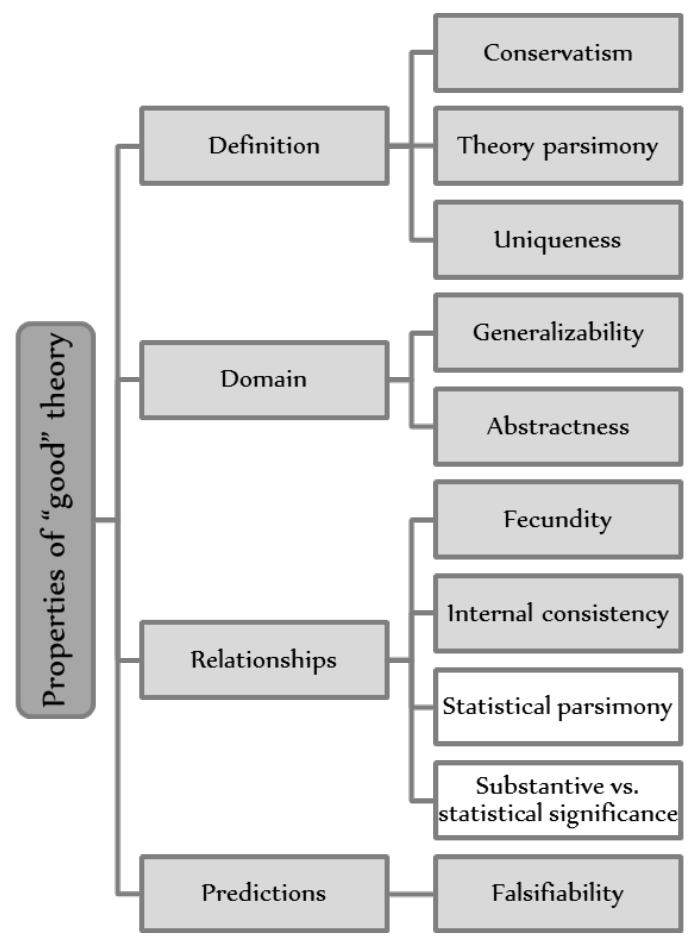

Figure 9: Properties of "good" theory (Wacker, 2008, p. 8)

Regarding the domain limitations (generalizability and abstractness), both conceptual models proposed in this study are limited to production facilities and applicable for both process industries and DIs, yet the specific emphasis of the S\&OP framework is on the continuous production characteristics. The relationships between the terms are logically developed; however, not all relationships are thoroughly investigated since the relations are not well covered in the literature yet. However, the integration of different concepts related to process industries (specifically continuous production) and DIs (discrete production) fulfills the fecundity criterion which according to Wacker (1998) provides opportunities for investigating new conceptual areas. The conceptual models are built on few well-established broadly-used concepts namely customer order decoupling point, see e.g. Hoekstra \& Romme (1992) and Mason-Jones, et al. (2000); and type of material flow, see e.g. Woodward (1965), which fulfills the theory parsimony criterion. The only exception is DiPo which has not been deeply investigated in the literature yet except in Pool, et al. (2011). Regarding the prediction properties, the suggested framework has not been applied in real world yet which means that the framework might be falsified as the result of empirical evidences.

\subsubsection{Validity and reliability}

Four types of validity and reliability are defined for qualitative research. Internal validity shows if the observations and the developed theories are well aligned (Bryman \& Bell, 2007). External validity is an indicator of the generalizability of developed theories (ibid.). Internal reliability questions the level of agreement between the observers/researchers when there is more than one observer/researcher and external reliability is concerned with the replicability of the research (ibid.). 
Conceptual research in general provides high external validity (Meredith, 1993); however, the degree of generalizability and abstractness differ between different theories which is an indicator of a "good" theory as discussed in 2.6.2. Internal reliability is applicable since this thesis is a compilation of papers which have been written by two authors. In order to improve the internal reliability, the authors have had extensive discussions and information sharing in different phases of idea generation, research, idea development and reporting the results. Regarding the external reliability, the research process is replicable through conducting the reviews and analysis. On one hand, it can be argued that logical reasoning and deductive approach provide the possibility to replicate the research but on the other hand, if theory-building is looked upon as a creative process, different people might follow different mind maps leading to differentiated ideas and theories. Due to the deductive approach of the study, the internal validity is not applicable. 


\section{Frame of references}

This chapter describes the concepts which build the foundation of this thesis. It starts with a general description about process industries and their specific characteristics since the main focus of this study is on process industries. It then continues with supply chain management issues, manufacturing planning and control and specifically S\&OP while emphasizing the role of S\&OP in supply chain integration.

\subsection{Process industries}

Process industries have a crucial role in terms of GDP in many countries. Operations management research though has not paid much attention to process industries until the 1980s (Kallrath, 2002) (Van Donk \& Fransoo, 2006). Process industries are defined as firms that "add value by mixing, separating, forming and/or chemical reactions by either batch or continuous mode" (Fransoo, 1993, p. 187). Some examples are petroleum, steel, pharmaceutical and paper industries (Taylor \& Bolander, 1994).

Different characteristics have been mentioned in the literature for process industries. Fransoo \& Rutten (1994, p.50) mention 15 characteristics for process industries including variable yield, variable quality, quantity (availability) and recipe; divergent flow of material and bill of material (related to the production of by-products); and price of raw materials. Ashayeri, et al. (1996) mention 28 features classified under four groups: relationship with the market, production process, quality, production and control. They name environmental demands, danger and quality measurements under the quality group which are considered to be highly important for the process industry but of less importance for Dls. Finch \& Cox (1988) mention 35 different characteristics divided into two groups: general characteristics such as the importance of co-products balance and high intermediate products demand; and the factors which affect the MPC design such as demand seasonality and the natural sequencing problem in production. All these classifications though are based on the initial studies by Taylor and his group in the late 1970s (Van Donk \& Fransoo, 2006). This initial classification included two groups of properties: product and market, and manufacturing properties (Taylor, et al., 1981) (Taylor \& Bolander, 1994). Their classification of process industries then was based on the product-process matrix by Hayes \& Wheelwright in 1979. According to these classifications, process industries have been considered as one integrated entity with one set of characteristics.

In another attempt to classify process industries, Dennis \& Meredith (2000a) compared 19 process industry sites based on four criteria namely materials diversity, equipment, materials movement and run time. They then suggested that the process industry companies in their study can be categorized under three main groups of intermittent type, hybrid type and continuous type which are further divided into seven subgroups. The intermittent type includes process job shop, custom blending, and fast batch; the hybrid type consists of custom and stock hybrid; and the continuous type includes multistage continuous and rigid continuous (Dennis \& Meredith, 2000a). As can be noticed, the main focus in the classifications has been on the production process/layout.

The general characteristics of process industries have been discussed so far. The following parts of this chapter are mainly focused on supply chain management/operations management issues. 


\subsection{Supply chain management}

First, it is important to distinguish between supply chain and supply chain management. According to APICS dictionary supply chain (SC) is "the global network used to deliver products and services from raw materials to end customers through an engineered flow of information, physical distribution, and cash" (Blackstone Jr., 2010). It includes the focal company as well as its tiers of suppliers, third party logistics and customers to mention a few. Supply chain management (SCM) then is "the design, planning, execution, control, and monitoring of supply chain activities with the objective of creating net value, building a competitive infrastructure, leveraging worldwide logistics, synchronizing supply with demand, and measuring performance globally" (ibid). The Council of Supply Chain Management Professionals (CSCMP) defines SCM as "an integrating function with primary responsibility for linking major business functions and business processes within and across companies into a cohesive and high-performing business model (CSCMP, 2014). The aim of SCM therefore is "the supply chain which represents a network of organizations that are involved, through upstream and downstream linkages, in the different processes and activities that produce value in the form of products and services in the hands of the ultimate customer" (Stadtler, 2008, p. 9).

SCM has two main building blocks: integration which deals with leadership, and partners' selection and collaboration; and coordination which is concerned with the use of information technology, orientation and planning (Stadtler, 2008, p. 12). The value of supply chain management and integration has been emphasized in the literature; see e.g. van Donk \& van der Vaart (2005) and Feng, et al. (2008). Still, the scope of integration in the context of supply chain is mainly limited to companies' distribution centers and the first tier of suppliers/customers (Shah, 2005) (Feng, et al., 2008). Better collaboration and communication between the partners and improved integration and visibility are useful ways to mitigate the supply chain risk due to the increased complexity and cost of the chain (Aberdeen Group, 2012). It also decreases the uncertainties regarding the demand volume and mix, manufacturing processes and supply (van Donk \& van der Vaart, 2005). Planning and integration are further discussed in 3.4 and 3.5.

Various factors influence the companies' decision about the appropriate supply chain including delivery lead-time, demand uncertainty and variability, demand volume, product life cycle stage, product variety (Pagh \& Cooper, 1998) (Childerhouse, et al., 2002) (Godsell, et al., 2011); and position of the customer order decoupling point (Hoekstra \& Romme, 1992) (Mason-Jones, et al., 2000) (Wikner \& Rudberg, 2005). Therefore, each company might benefit from several supply chains for different products/product families, see e.g. Fisher (1997), Childerhouse, et al. (2002), Aitken, et al. (2003), Godsell, et al. (2011) and Christopher $\&$ Holweg (2011). The Company's capability in managing its various supply chains is the key to competitiveness (Olhager, 2013).

\subsection{Planning and control system design}

Based on the aims of their SCs, companies design their planning and control systems which depend on several factors including the products (type of object), the production processes and their repetitivity (mode type), and the customers' demands and needs (driver of the flow), see e.g. Dennis \& Meredith (2000a) and Maccarthy \& Fernandes (2000). A review of 
different factors influencing the system design can be found in Maccarthy \& Fernandes (2000). Types of object, mode and driver are further discussed below.

\subsubsection{Object type}

According to Abdulmalek, et al. (2006), the transformed materials (here referred to as objects) in the production flow can be of two types: continuous and discrete. Based on the definition, Dls operations are only focused on discrete objects. process industries; however, are actually hybrids meaning that in their production process, there is a point where continuous objects (CO) turn into discrete objects (DO) and discrete products are produced (Woodward, 1965) (Billesbach, 1994) (Finch \& Luebbe, 1995) (Dennis \& Meredith, 2000a) (Abdulmalek, et al., 2006) (Abdulmalek \& Rajgopal, 2007) (van der Zee, et al., 2008) (Lyons, et al., 2011). This point is referred to as "discretization point" (DiPo) (Pool, et al., 2011, p. 194). DiPo emphasizes the transformation of the physical attribute of the product from uncountable continuous to countable discrete (Abdulmalek, et al., 2006). The importance of this transformation point is in its influence on the types of production processes which are the basis for definition of process industries i.e. mixing, separating, forming and chemical reactions since these processes are usually performed on continuous objects (Fransoo \& Rutten, 1994) (Finch \& Luebbe, 1995).

Discretization point can be used as a point of reference to define process industries with focus on their flow characteristics in contrast with production layout, see e.g. Finch \& Luebbe (1995) and Dennis \& Meredith (2000a) or product-process interaction, see e.g. Hayes \& Wheelwright (1979a), Hayes \& Wheelwright (1979b), Taylor, et al. (1981), Taylor \& Bolander (1994), Fransoo \& Rutten (1994) and Ashayeri, et al. (1996). Thus, while discussing the differentiating characteristics of continuous production and discrete production, the influential factor is the continuity of the object which affects the choice of the production processes including resources (Fransoo \& Rutten, 1994).

\subsubsection{Mode type}

The production system design is influenced not only by the demand pattern but also the way the company responds to the demand in terms of frequency of production (Finch \& Luebbe, 1995) (Arnold, et al., 1998). This issue addresses the transformation of the products through the processes and is referred to as mode type or as suggested by Maccarthy \& Fernandes (2000), repetitivity. Three different modes can be identified based on the level of repetitivity ranging from one-time to continuous mode. The mode between these two extremes is referred to as intermittent which happens when transformation process is recurring.

One-time flow is used when the demand is low and irregular, the product is complex and the lead-time is long (Jacobs, et al., 2011). The intermittent mode is applicable when the demand is recurring, the material flows at time intervals and the production is done in batches, lots (Arnold, et al., 1998) or campaigns (Taylor \& Bolander, 1994). The term "campaign" is usually used in the process industries context (Taylor \& Bolander, 1994). It also implies that the products can be transported between two successive resources before the whole campaign is ready on the preceding resource. In discrete production this concept is referred to as overlapping (Blackstone Jr., 2010). Continuous mode is applicable when the demand is high and homogenous and the products flow continuously through the processes and the time gap between successive units is neglectable (Jacobs, et al., 2011). The underlying point in this context is set-up time which affects the planning system design (Olhager \& Rudberg, 2002). 
In continuous mode the set-up time can be neglected in case there is only one object or no set-up is required between the successive objects (e.g. within a product family) but in intermittent mode, set-up time/cost is an important factor which among others influences the batch size.

In process industries, only two of the modes are applicable: continuous and intermittent (Woodward, 1965) (Fransoo, 1993) (Dennis \& Meredith, 2000a) (Blackstone Jr., 2010). Set-up time is crucial for process industries and specifically the continuous production since for these companies set-ups are long and partly sequence-dependent (Taylor \& Bolander, 1994) (Van Donk, 2001) (Mclntosh, et al., 2010). Cleaning is an important part of the set-up time especially in food or pharmaceutical industries (ibid).

\subsubsection{Driver type}

The trigger of the material flow or the transformation process is referred to as the driver type which is directly related to the customer demand. It should be noted that the driver type only refers to the trigger of the flow and is not concerned with the customization of products for specific customers (Hoekstra \& Romme, 1992). As shown in Figure 10, based on the trigger of the transformation process, two driver types can be distinguished: forecast driven (speculation) and customer order driven (commitment), see e.g. Giesberts \& Van Der Tang (1992), Hoekstra \& Romme (1992) and Pagh \& Cooper (1998). While the forecast driven part is based on planning and anticipation of customers' needs, the customer order driven part deals with the known/confirmed requests of the customers (ibid). The transition point between these two parts is referred to as customer order decoupling point (CODP) (Giesberts \& Van Der Tang, 1992) which specifies how far the customer order penetrates in the manufacturing process and is usually related to a stock point (Hoekstra \& Romme, 1992) (Wikner \& Rudberg, 2005). CODP is also known as order penetration point (Sharman, 1984) (Olhager, 2003), delayed differentiation (Akkerman, et al., 2010) and postponement (Towill, 2005).

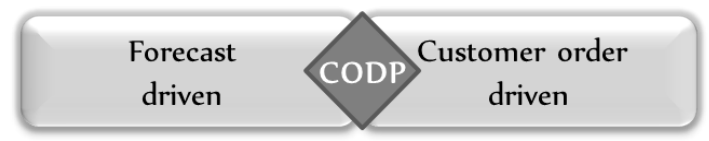

\section{Figure 10: Driver type and customer order decoupling point (CODP) based on Wikner (2014)}

Based on the position of the CODP, four different manufacturing strategies are recognized: engineer-to-order (ETO), make-to-order (MTO), assemble-to-order (ATO) which is also referred to as finish-to-order (FTO), and make-to-stock (MTS). The degree of customization decreases from ETO to MTS (Giesberts \& Van Der Tang, 1992). CODP stock point can be located at suppliers, raw materials, work-in-process parts and components, and finished goods for ETO, MTO, ATO and MTS respectively. Thus, CODP can ultimately be located at any stock point in the supply chain (Van Hoek, 2001).

Due to the economic situation and the competitive environment, many companies are moving from pure MTS/MTO to hybrid models i.e. combined MTS-MTO such as ATO/FTO (Soman, et al., 2004) by moving CODP upstream for MTS or adding customized operations in the downstream (Hoekstra \& Romme, 1992). Postponement strategy practice in process industries though lags behind the discrete manufacturers (Mclntosh, et al., 2010) due to the cost of low utilization of equipment, the possibility of decoupling the production process and 
adding buffers, the capacity of the buffers and the selection of intermediate products (Van Hoek, 1999) (Caux, et al., 2006) (Akkerman, et al., 2010) (Sharda \& Akiya, 2012) (Kilic, et al., 2013).

\subsection{Manufacturing planning and control}

The supply chain goals and the factors considered in the design of a planning and control system in turn affect the companies' manufacturing planning and control. Manufacturing planning and control is a closed-loop information system which provides information and support for different decision making activities in a company related to materials management, resource planning and coordination of key suppliers and customers (Blackstone Jr., 2010) (Jacobs, et al., 2011). The planning activities can be studied based on time as well as control perspectives, see e.g. Gorry \& Morton (1971) and Little, et al. (1995).

From the control perspective three levels are distinguished: strategic, tactical and operational, see e.g. Wight (1984). Strategic level addresses activities in relation to the company's goals and objectives affecting its position in the business environment (Gorry \& Morton, 1971) (Finch \& Luebbe, 1995) (Jonsson \& Mattsson, 2009) (Blackstone Jr., 2010). Tactical level activities provide the tactical plans (sales, production, marketing, etc.) and try to balance different functions in the company in order to achieve the intermediate goals and objectives as well as to support the strategic level decisions (ibid). The operational level is concerned with day-to-day activities and detailed schedules for different functions (ibid).

From the time perspective activities can cover a long, medium or short horizon. Long-term planning is responsible for providing resources to meet the future needs of the market based on the desired position of the company in the business environment (Taylor \& Bolander, 1994) (Finch \& Luebbe, 1995). From a broader perspective, long-term planning should provide a basis for design of the company's supply chain based on future needs (Fleischmann, et al., 2008). Medium-term planning aims to balance demand and supply in a way to provide an outline for the main operations and the short-term planning addresses the detailed instructions for all the activities on a daily basis (ibid).

These two perspectives are interwoven meaning that strategic, tactical and operational plans have long, medium and short horizons as well as the level of aggregation and the scope of decisions decreases respectively (Hax \& Meal, 1975) (Fleischmann, et al., 2008) (Pool, et al., 2011). The concept of hierarchical planning emphasizes that the higher levels in the hierarchy impose restrictions on the lower levels' activities and decisions and thus aligns all the activities on different levels with centralized planning (ibid). This method has been broadly used in the literature related to planning in process industries as well; see e.g. Fransoo (1993), Kallrath (2002) and Feng, et al. (2008).

Another structure for MPC is to divide the activities based on their time horizon and the level of detail to business plan, sales and operations plan, master production schedule, detailed production schedule and production activity control, see e.g. Finch \& Luebbe (1995), Arnold, et al. (1998) and Olhager \& Rudberg (2002). Two perspectives of material and capacity are also added into this structure (Little, et al., 1995). Figure 11 shows the structure used in this licentiate which is compiled from the above mentioned research. S\&OP and MPS are located between strategic-tactical and tactical-operational respectively. This is due to the fact that they cover activities with different time horizons and impacts. 


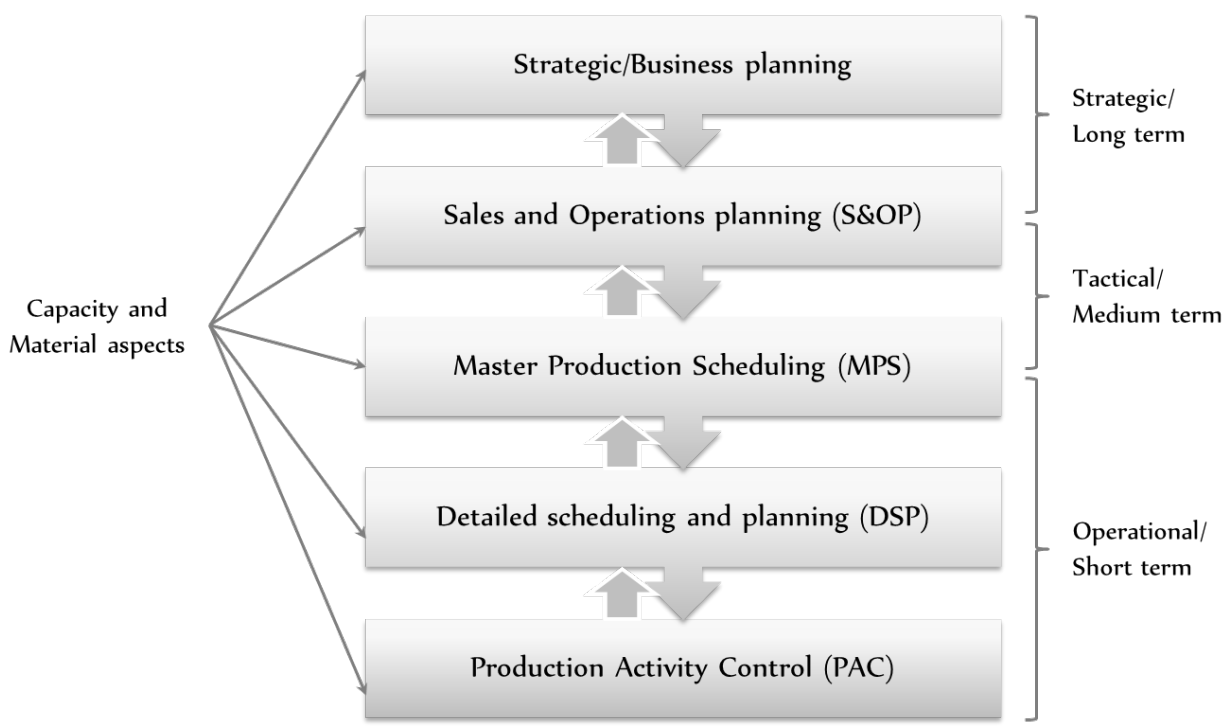

Figure 11: Manufacturing planning and control system

Taylor \& Bolander (1994) takes a different view and introduce a process flow systems framework for process industries which is based on process structure rather than the product structure. In their framework, they consider production plans for divisions, plants, process trains, and stages and clusters (Taylor \& Bolander, 1994, pp. 54-59). The plans for divisions, plants and trains can be compared to business, S\&OP and MPS respectively but there are some overlaps. S\&OP, also referred to as production planning (Wight, 1984) (Taylor \& Bolander, 1994) or aggregate production planning (Holt, et al., 1955), is the subject of the next part.

\subsection{Sales and operations planning}

The starting steps of S\&OP was taken in 1950s by Holt, Modigliani, Muth and Simon when they initiated the work on aggregate production planning and forecasting (Holt, et al., 1955) (Singhal \& Singhal, 2007) (Feng, et al., 2011). Some other authors though state that S\&OP has emerged from MRPII and been improved since 1970s (Wight, 1984) (Ling \& Goddard, 1988) (Basu \& Wright, 2008). S\&OP has improved further during recent years due to the advancement of information and communication technology (Olhager, 2013) and in response the fierce competition, tough economic situation (Atkinson, 2009), globalization complexities (Jonsson, 2011) (Lim, et al., 2014), and the ongoing trend of outsourcing (Klappich, 2012). S\&OP has been considered as the stepping stone before the advent of supply chain planning (Olhager, 2013) and is referred to as "the key to success" (Wight, 1984, p. 142), the supply chain pillar (Affonso, et al., 2008), "steering wheel for a company's business" (Lapide, 2009, p. 4) and the integrator of total supply chain management (Basu \& Wright, 2008).

\subsubsection{Definition and scope}

Different names have been used to describe this process including enterprise S\&OP; executive S\&OP; integrated business management (IBM); sales, inventory and operations planning; S\&OP II (APICS, 2011) and sales, operations and financial planning (Maskell \& 
Baggaley, 2004). In this thesis, only the term S\&OP (Ling \& Goddard, 1988) is used when referring to all these expressions to avoid any misinterpretation.

Accordingly, different definitions with various scopes have been presented. Traditionally, $\mathrm{S} \& \mathrm{OP}$ is defined as "a dynamic process in which the company operating plan is updated on a regular monthly or more frequent basis" (Ling \& Goddard, 1988, p. 11), "a senior management review process of establishing the operational plan and other key activities of the business to best satisfy the current level of sales forecast according to the delivery capacity of business" (Basu \& Wright, 2008, p. 314) and "a set of business processes that helps companies keep demand and supply in balance" (Wallace \& Stahl, 2008, p. 9). Arnold, et al. (1998, p. 20) suggests that S\&OP is a proactive process "for continually revising the strategic business plan and coordinating plans of various departments". APICS dictionary defines S\&OP as "a process to develop tactical plans that provide management the ability to strategically direct its businesses to achieve competitive advantage on a continuous basis by integrating customer-focused marketing plans for new and existing products with the management of the supply chain. The process brings together all the plans for the business (sales, marketing, development, manufacturing, sourcing, and financial) into one integrated set of plans" (Blackstone Jr., 2010). To achieve the balance between demand and supply plans, integration of people from different areas both within (Ling \& Goddard, 1988) and outside the company's boundary is essential which provides a platform for inter/intracompany discussion and decision making (Affonso, et al., 2008) (Oliva \& Watson, 2011) (Thome, et al., 2012a).

S\&OP aims to integrate the demand and the supply plan at an aggregate level on a monthly basis (Ling \& Goddard, 1988) (Wallace, 1999) (Wallace \& Stahl, 2008) (Jonsson, 2011). The suggested planning horizon ranges between three months and three years (Gianesi, 1998) (Grimson \& Pyke, 2007), while emphasis is on a horizon between 12-18 months (Wallace \& Stahl, 2008) especially for companies with seasonality profile in order to cover the whole marketing cycle (Grimson \& Pyke, 2007). S\&OP is mainly located at tactical level in the hierarchy of planning. However, when this process deals with scenario management, risk assessment (Wallace \& Stahl, 2008) or the expansion of capacity (Olhager, et al., 2001) (Olhager \& Selldin, 2007) (Thome, et al., 2012a), it has extensions towards the strategic level (Olhager \& Rudberg, 2002) (Wallace \& Stahl, 2008) (Alexander, 2013).

\subsubsection{S\&OP process}

As mentioned earlier, S\&OP is a planning process rather than a mathematical model. Most authors follow a five-step process for this process (Wallace, 1999) (Jacobs, et al., 2011) as shown in Figure 12.

The process starts with data gathering for demand and supply planning and in the second step a demand plan is prepared. Demand planning is mainly focused on forecasting the demand for present and new products based on history, competitors' activities, management directives and economic situation. This plan is then sent to the supply planning step where the capacity planning is performed based on the demand plan, available capacity and inventory/backlog levels. 


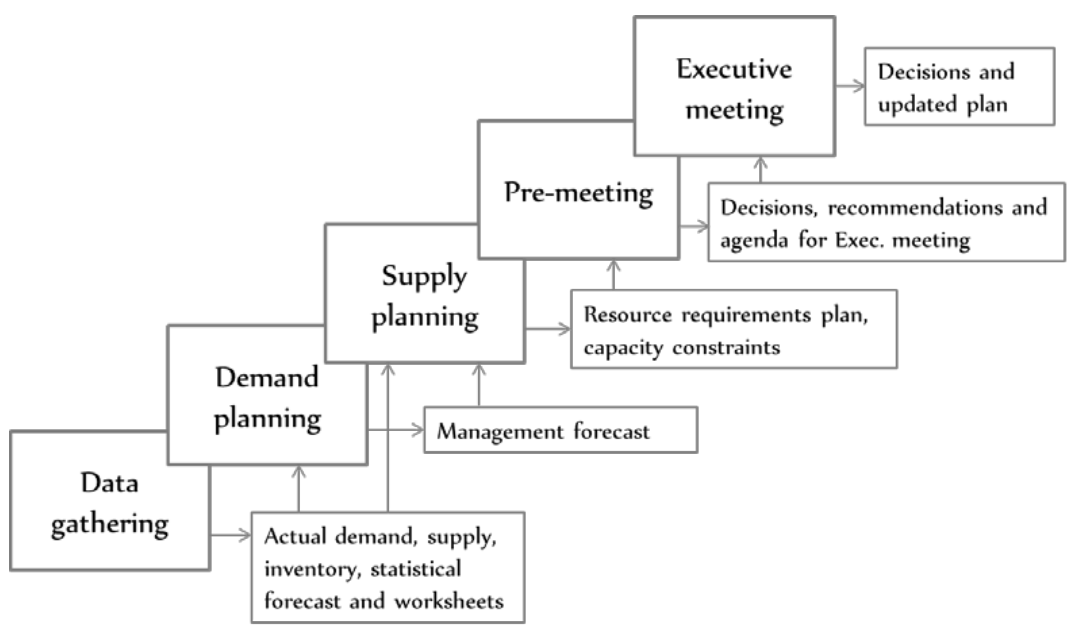

Figure 12: S\&OP process (Wallace, 1999)

The two final steps are designed to integrate related people from different areas and provide a platform for group discussion and decision making in order to achieve balance between demand and supply sides (Wallace, 1999) (Wallace \& Stahl, 2008) (Singh, 2010). The aim is to overcome the functional silos in the company (Ling \& Goddard, 1988) and connect different functions with various - even contradictory - objectives in a way to function as a whole (Shobrys \& White, 2002). This feature is related to the inter-company horizontal integration (Shobrys \& White, 2002) (Affonso, et al., 2008).

Nevertheless, companies nowadays have extended their focus towards the supply chain and their external partners such as suppliers, customers, competitors and distributers. Thus, the scope of S\&OP is widened to cover the supply chain partners as well (Lapide, 2005) (Grimson \& Pyke, 2007) (Wallace \& Stahl, 2008). This feature is related to the intra-company integration (Affonso, et al., 2008).

\subsubsection{Results and metrics}

In order to keep the S\&OP process improving, it is crucial to define the related metrics and their desired value for S\&OP process. Metrics can differ between different companies based on their planning system design. Some common metrics are line fill (Grimson \& Pyke, 2007), asset utilization (Hahn \& Kuhn, 2012), inventory (end product, raw material and work-inprocess) level, forecast accuracy, on-time delivery (Davis \& Novack, 2012), forecast volatility (Chae, 2009), and financial metrics such as revenue (Alexander, 2013), profitability (Cecere, 2005) (Muzumdar \& Fontanella, 2006), cash conversion cycle and gross profit margin (Viswanathan, 2011). For the full list of quantitative benefits and metrics, the readers are referred to Thome, et al. (2012a).

A successful implementation of the S\&OP process has fruitful results for the companies. It should be noted that S\&OP is first and foremost about the people involved in the process and their integration rather than a set of spread-sheets and software (Wallace, 1999). In accordance with this point-of-view, Wallace (2006) considers two different types of benefits for S\&OP: hard (quantitative/measurable) and soft (qualitative/hard to measure). The first group includes benefits such as lower uncertainty (Muzumdar \& Viswanathan, 2009) (APICS, 
2012), customer satisfaction (Muzumdar \& Fontanella, 2006), improved inventory turns, improved service (Basu \& Wright, 2008) (Atkinson, 2009), improved time to market (Sabri \& Shaikh, 2013), better forecast accuracy (Grimson \& Pyke, 2007), reduced out-of-stock (Prokopets, 2012), improved operational performance (Gianesi, 1998) (Thome, et al., 2012b) and optimized customer service vs. inventory level and cost (Thome, et al., 2012a).

The second group includes improved visibility (Muzumdar \& Viswanathan, 2009) (Ivert \& Jonsson, 2010) (APICS, 2012), better communication and cooperation between personnel and management (Jacobs, et al., 2011) and between different functions in a company (Ling \& Goddard, 1988) (Gianesi, 1998) (Grossmann, 2005) (Wallace, 2006), improved organizational behavior (Shobrys \& White, 2002), better decisions with less effort (Wallace, 2006) and maintaining long-term relationship with customers (Muzumdar \& Fontanella, 2006).

So far, the fundamental concepts being used in this thesis have been discussed. The next chapter covers the way these concepts have been deployed and further developed in order to fulfill the ROs and the purpose of this thesis. 



\section{Summary and contribution}

As mentioned in 1.3, three research objectives have been defined for this thesis. Each of the papers appended covers one of the ROs. In this chapter the contribution of the papers and their relation to ROs, and the contribution of the authors are discussed.

\subsection{Paper 1: Sales and operations planning in the process industry}

The first paper includes a systematic literature review about S\&OP in process industries. Three databases were selected: ScienceDirect, Emerald, and Taylor and Francis. The keywords were searched in the title, abstract and keywords of the papers from 1980-2012. In addition, articles from professional and business journals have been reviewed in order to identify the recent developments in this area. Two journals of this type were selected according to other researchers' recommendation. All articles about S\&OP in "Supply chain management review" magazine from 2000-2012 and "Supply chain quarterly" from 2007-2012 were reviewed. An earlier version of this paper has been presented in EurOMA Conference, Dublin, Ireland, 2013.

It should be noted that in this paper, the concepts of object type and mode type were not differentiated and the terms continuous production and discrete production have been used instead of the object type and the mode type.

\subsubsection{Purpose}

The purpose of the review has been to study S\&OP in process industry. Due to the fact that there has not been much written about this subject in the literature, the aim was to investigate, first, the present situation of S\&OP in process industries and second, the desired future status of this process based on the identified gaps as well as specific characteristics of process industries. This paper is aligned with RO1.

\subsubsection{Contribution of the paper}

Regarding the first part of RO1, the definition of process industry has been scrutinized through the concept of DiPo. The aim has been to find out whether or not the reviewed papers considered different characteristics of continuous object (CO) and discrete object (DO) at each side of DiPo. The results are shown in Table 1 . As can be noticed, the column about typical DO characteristics is blank which indicates that the literature has not mentioned any typical characteristics related to DO. So for the DO part, the generic characteristics should be considered.

Through the review process and in order to classify the papers, a research synthesis has also been defined, see Figure 13. This synthesis has provided the opportunity to compare the advancement of S\&OP in process industries with Dls which is in line with the second part of RO1. Most of the found papers about S\&OP in process industries were quantitative and very much focused on the traditional definition of S\&OP rather than the integrated S\&OP as shown in Figure 13. In addition, only a few numbers of articles have explicitly considered DiPo as a point of reference in the S\&OP process. The other issue about most of these papers is that they do not consider the soft benefits of S\&OP process as discussed earlier and do not give a clear view about how S\&OP should be implemented in process industries. 
Table 1: Generic, DO and CO specific issues affecting sales and operations planning

\begin{tabular}{|l|l|l|l|l|}
\hline \multicolumn{2}{|l|}{ S\&OP attributes } & $\begin{array}{l}\text { Typical Do } \\
\text { characteristics }\end{array}$ & Generic characteristics & $\begin{array}{l}\text { Typical co } \\
\text { characteristics }\end{array}$ \\
\hline $\begin{array}{l}\text { Demand } \\
\text { planning }\end{array}$ & $\begin{array}{l}\text { Demand } \\
\text { forecasting }\end{array}$ & - & $\begin{array}{l}\text { Sales plan } \\
\text { Marketing plan } \\
\text { New products and customers }\end{array}$ & - \\
\hline \multirow{3}{*}{$\begin{array}{l}\text { Supply } \\
\text { planning }\end{array}$} & $\begin{array}{l}\text { Resources } \\
\text { utilization }\end{array}$ & - & $\begin{array}{l}\text { Staff planning } \\
\text { Investment in new resource } \\
\text { Aligned/Nonaligned resources }\end{array}$ & $\begin{array}{l}\text { Energy provision } \\
\text { and consumption } \\
\text { Variable yield }\end{array}$ \\
\cline { 2 - 5 } & - & $\begin{array}{l}\text { Production capacity restriction } \\
\text { Inventory/Backlog level } \\
\text { Bottlenecks }\end{array}$ & $\begin{array}{l}\text { Inventory capacity } \\
\text { restriction } \\
\text { Maintenance plans } \\
\text { integration }\end{array}$ \\
\cline { 2 - 6 } & Material & - & $\begin{array}{l}\text { Long lead-time materials } \\
\text { flowgent material } \\
\text { Variable recipe }\end{array}$ \\
\hline \multirow{2}{*}{ Balancing } & $\begin{array}{l}\text { Balance of } \\
\text { demand } \\
\text { and supply }\end{array}$ & - & $\begin{array}{l}\text { Integration of different parties } \\
\text { involved in the process }\end{array}$ & - \\
\hline
\end{tabular}

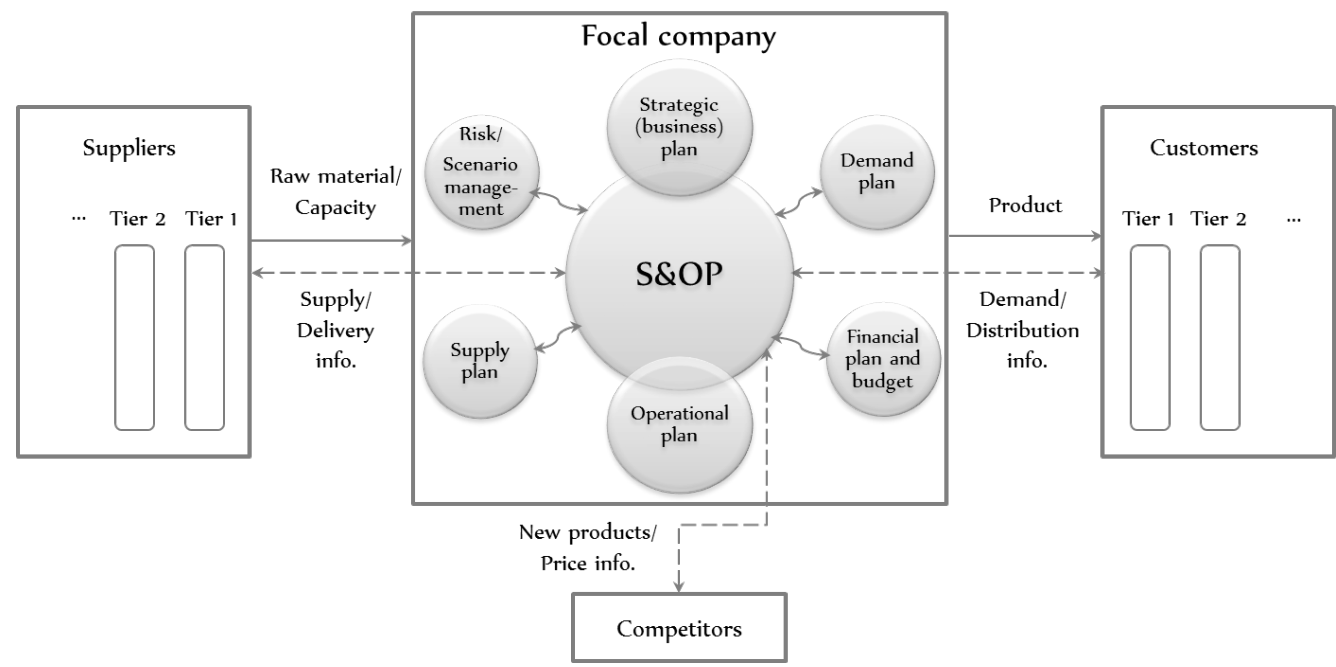

Figure 13: Sales and operations planning in the supply chain context

\subsection{Paper 2: Typology for planning and control - Combining object type, mode type, and driver type}

This paper concerns planning and control of manufacturing and logistics activities within the supply chain and defines a typology through logical reasoning and based on inputs from the literature in previous research related to decoupling theory, planning and control and particularly sales and operations planning in the process industry. An earlier version of this 
paper has been presented in the International Conference on Sustainable Design and Manufacturing, Cardiff, Wales, United Kingdom, 2014.

\subsubsection{Purpose}

This paper aims to propose a typology of key dimensions that are fundamental in the design of planning and control systems. The intention is to suggest a general typology, based on the flow characteristics, which covers both process industries (mainly in relation to the continuous production) and DIs (discrete production) and integrates the concepts from both sides. Hybridity within each dimension and cross-hybridity between the dimensions have been studied as well. This paper is in line with RO2.

\subsubsection{Contribution of the paper}

The typology developed in this paper is based on flow characteristics rather than the layout of production facilities since the flow characteristics affect the resource management and thus the layout. These characteristics are object type (OT), and hence also production processes and resource properties; mode type (MT) and driver type (DT) as discussed in 3.3.1, 3.3.2 and 3.3.3 respectively. The typology is illustrated in Figure 14 and covers both continuous production and discrete production through continuous and discrete object types. Hybrid driven in this figure represents a combination of speculation and commitment driven. Some of the states i.e. CO-OM-SD, CO-OM-HD, CO-OM-CD, DO-OM-SD and DO-OM$\mathrm{HD}$ are shown with white in the figure below since they are not likely to happen.

CO: Continuous Object

DO: Discrete Object

CM: Continuous Mode

IM: Intermittent Mode

OM: Onetime Mode

SD: Speculation Driven

HD: Hybrid Driven

CD: Comittment Driven

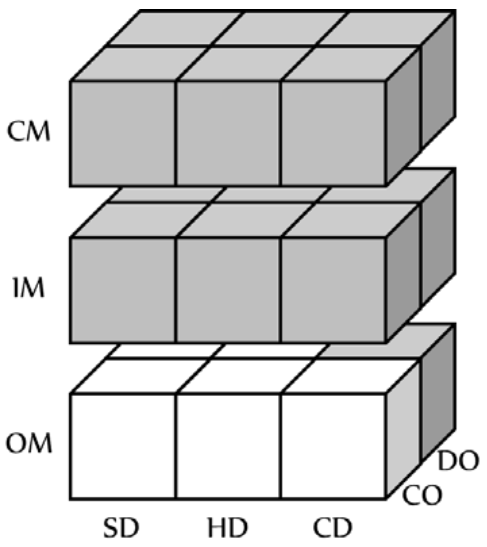

SD $\quad H D \quad C D$

Figure 14: Typology for planning and control (OT-MT-DT)

In addition, hybridity within each dimension and cross-hybridity between the dimensions are investigated as shown in Figure 15. 


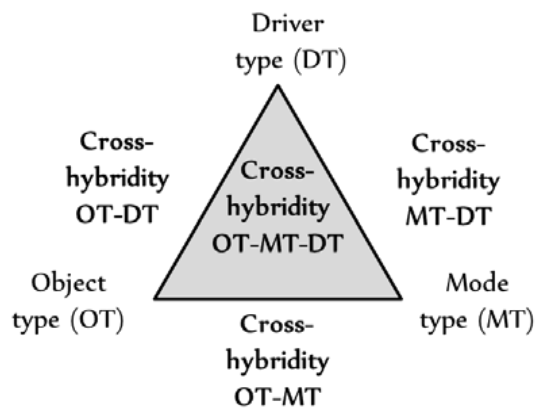

Figure 15: The four identified cross-hybridities

Based on this typology, process industries and DIs can be differentiated based on their supply type/flow properties as shown in Table 2. Dls in this context can be considered as a specific case when the DiPo is located in the beginning of the production process and thus the whole flow is based on the discrete objects.

Table 2: Differentiating characteristics between process industry and discrete manufacturing industry

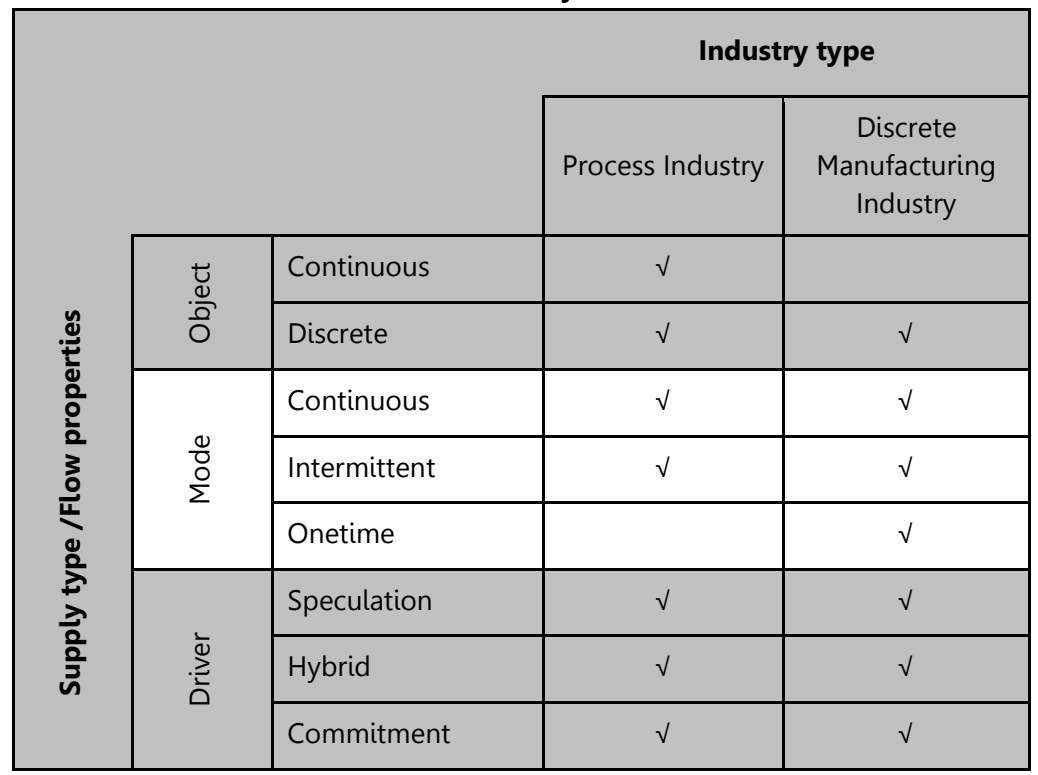

\subsection{Paper 3: Sales and operations planning in process industries based on types of object, mode and driver: An implementation guide}

The paper provides a conceptual framework of several concepts (i.e. object type, mode type and driver type as well as S\&OP) and the relationships between them. The framework suggested in this paper is a conceptual deduction which covers description and definition of the terms, and partly explanation and understanding of the relationships between them. An earlier version of this paper has been presented in the Eighteenth International Working Seminar on Production Economics, Innsbruck, Austria, 2014. 
It should be noted that in the conference version of P3, the terminology "flow" type has been used instead of "mode" type; however, both of these terms represent the same concept as discussed in 3.3.2.

\subsubsection{Purpose}

The purpose of this paper is to integrate the concepts of object type, flow type and driver type in the context of S\&OP. The aim is to distinguish the specific characteristics influencing the design/implementation of S\&OP and to provide the foundation for a differentiated $\mathrm{S} \& O P$ process for process industries. This paper is in line with RO3.

\subsubsection{Contribution of the paper}

In this paper, a modified version of the typology from P2 is used. This version is more focused on process industries' properties i.e. the continuous production. Thus, the onetime mode and the hybrid driver are excluded and as a result, the simplified version with eight building blocks based on object type, mode type and driver type is obtained and then applied to S\&OP process. As in P2, hybridities and cross-hybridities in relation to S\&OP are studied as well. The results are shown in Table 3.

Table 3: Important issues in S\&OP process with regard to the eight building blocks

\begin{tabular}{|c|c|c|c|c|c|c|}
\hline \multirow{3}{*}{$\begin{array}{l}\text { Building } \\
\text { blocks }\end{array}$} & \multicolumn{6}{|c|}{ Important issues in S\&OP process } \\
\hline & \multicolumn{2}{|c|}{ Demand planning } & \multicolumn{2}{|c|}{ Supply planning } & \multicolumn{2}{|c|}{ Balancing } \\
\hline & $\begin{array}{c}\text { Backlog } \\
\text { level }\end{array}$ & $\begin{array}{c}\text { Order } \\
\text { acceptance }\end{array}$ & $\begin{array}{c}\text { Set-up } \\
\text { time }\end{array}$ & $\begin{array}{c}\text { Inventory } \\
\text { level }\end{array}$ & $\begin{array}{c}\text { Level } \\
\text { strategy }\end{array}$ & $\begin{array}{c}\text { Chase } \\
\text { strategy }\end{array}$ \\
\hline CO-CM-CD & $\sqrt{ }$ & $\sqrt{ }$ & & & $\sqrt{ }$ & $\sqrt{ }$ \\
\hline CO-CM-FD & & & & $\sqrt{ }$ & $\sqrt{ }$ & \\
\hline CO-IM-CD & $\sqrt{ }$ & $\sqrt{ }$ & $\sqrt{ }$ & & & $\sqrt{ }$ \\
\hline CO-IM-FD & & & $\sqrt{ }$ & $\sqrt{ }$ & $\sqrt{ }$ & $\sqrt{ }$ \\
\hline DO-CM-CD & $\sqrt{ }$ & $\sqrt{ }$ & & & $\sqrt{ }$ & $\sqrt{ }$ \\
\hline DO-CM-FD & & & & $\sqrt{ }$ & $\sqrt{ }$ & \\
\hline DO-IM-CD & $\sqrt{ }$ & $\sqrt{ }$ & $\sqrt{ }$ & & & $\sqrt{ }$ \\
\hline DO-IM-FD & & & $\sqrt{ }$ & $\sqrt{ }$ & $\sqrt{ }$ & $\sqrt{ }$ \\
\hline
\end{tabular}

In case of cross-hybridity, the balance of capacity between continuous and intermittent modes and capacity allocation between forecast driven and customer order driven parts should be considered. Table 4 shows the possible cross-hybridities in process industries, note that the first column in the table below contains only continuous object to emphasize the focus on the process industries and the continuous production in particular. 
Table 4: Possible cross-hybridities within the process industries

Table legend

CO: Continuous object

DO: Discrete object

CM: Continuous mode

IM: Intermittent mode

FD: Forecast driven

CD: Customer order driven

\begin{tabular}{|c|c|}
\hline \multicolumn{2}{|c|}{ Cross-Hybrid } \\
\hline $\begin{array}{c}\text { Of } \\
\text { (Possible beginning states) }\end{array}$ & $\begin{array}{c}\text { And } \\
\text { (Possible following states) }\end{array}$ \\
\hline \multirow{4}{*}{ CO-CM-FD } & CO-IM-FD \\
\cline { 2 - 2 } & DO-CM-FD \\
\cline { 2 - 2 } & DO-IM-FD \\
\cline { 2 - 2 } & CO-IM-CD \\
\cline { 2 - 2 } & DO-IM-CD \\
\cline { 2 - 2 } & CO-CM-CD \\
\hline \multirow{4}{*}{ CO-CM-CD } & DO-CM-CD \\
\cline { 2 - 2 } & DO-CM-CD \\
\cline { 2 - 2 } & CO-IM-CD \\
\hline \multirow{4}{*}{ CO-IM-FD } & DO-IM-CD \\
\hline \multirow{4}{*}{} & DO-IM-FD \\
\cline { 2 - 2 } & CO-IM-CD \\
\hline CO-IM-CD & DO-IM-CD \\
\hline
\end{tabular}

As an example from Table 4, a production system can be a hybrid of CO-CM-FD and DO-IM$C D$ which represents a finish-to-order company with DiPo in the middle of the production process that produces first in continuous mode and then based on campaigns/batches.

On the basis of these results, an implementation guide for the S\&OP framework has also been outlined as shown in Figure 16.

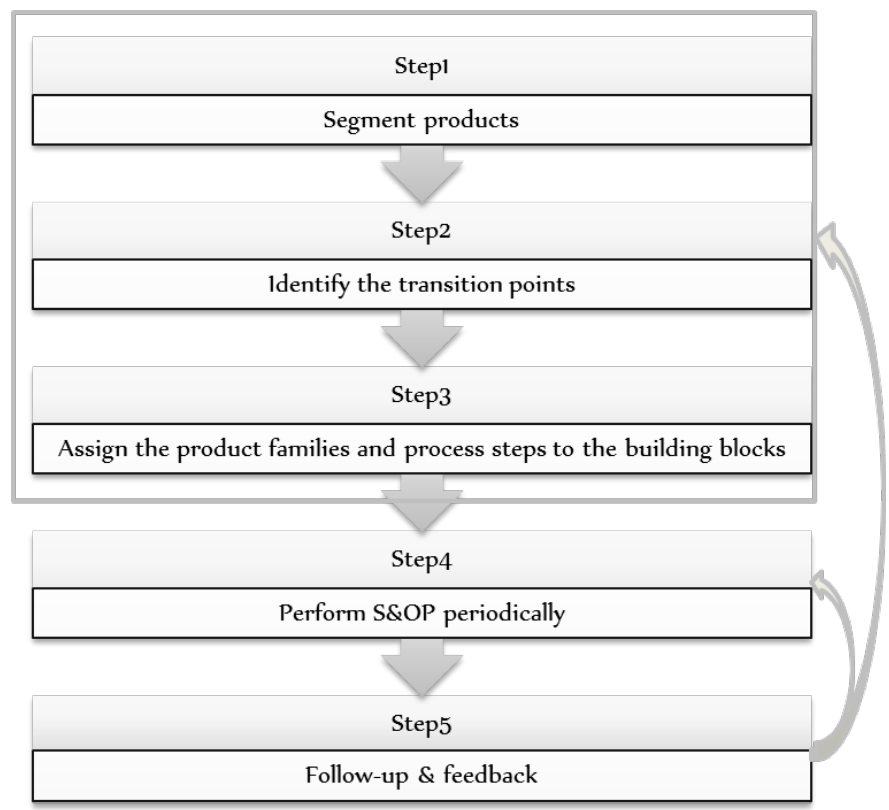

Figure 16: S\&OP framework implementation steps 


\subsection{Authors' contribution in the papers}

In this part, the authors' contribution in each paper is presented. The list of the publications is provided below.

Table 5: List of publications

\begin{tabular}{|c|l|l|l|}
\hline $\begin{array}{c}\text { Paper } \\
\text { no. }\end{array}$ & \multicolumn{1}{|c|}{ Title } & \multicolumn{1}{c|}{ Authors } & \multicolumn{1}{c|}{ Type } \\
\hline 1 & $\begin{array}{l}\text { Sales and operations planning in } \\
\text { the process industry }\end{array}$ & $\begin{array}{l}\text { Noroozi \& Wikner } \\
(2013)\end{array}$ & $\begin{array}{l}\text { Conference paper, EurOMA } \\
\text { conference }\end{array}$ \\
\hline 2 & $\begin{array}{l}\text { Typology for planning and } \\
\text { control - Combining object type, } \\
\text { mode type, and driver type }\end{array}$ & $\begin{array}{l}\text { Wikner \& Noroozi } \\
(2014)\end{array}$ & $\begin{array}{l}\text { Conference paper, } \\
\text { International Conference on } \\
\text { Sustainable Design and } \\
\text { Manufacturing }\end{array}$ \\
\hline 3 & $\begin{array}{l}\text { Sales and operations planning in } \\
\text { process industries based on types } \\
\text { of object, mode and driver }\end{array}$ & $\begin{array}{l}\text { Noroozi \& Wikner } \\
(2014)\end{array}$ & $\begin{array}{l}\text { Conference paper, 18th } \\
\text { International Working Seminar } \\
\text { on Production Economics }\end{array}$ \\
\hline
\end{tabular}

\subsubsection{Paper 1}

I had the main role in paper1. The keywords being used in the search engines were a result of discussion and brain-storming between me and both my advisors but the literature review was conducted by me. In the analysis part, the S\&OP synthesis has been suggested by me; however, the integration of DiPo in the analysis and discussion was based on my main advisor's suggestion.

\subsubsection{Paper2}

In this paper, my main advisor had the main role in introducing the typology and writing the paper. The idea of object type has been an input from P1. My part was to help positioning the paper in the body of literature. This paper has been an input to P3 but from a chronological perspective, P3 was written first. Thus, we had extensive discussions about the typology beforehand which acted as an input to both of the papers.

\subsubsection{Paper3}

This paper applies the typology from P2 to S\&OP with focus on process industries. I had the main role in defining the S\&OP framework and writing the paper. My main advisor has provided support for the typology and contributed in structuring the paper and in the analysis part. 



\section{Concluding discussion and further research}

The aim of this thesis is to scrutinize the concept of sales and operations planning (S\&OP) in the process industry and to investigate how process industries' specific characteristics should be integrated into a differentiated S\&OP framework.

In this study, mainly qualitative and theory-building methodologies have been applied. This is due to the fact that most of the papers about S\&OP in process industries are quantitative rather than qualitative and company-specific and thus, the need for conceptual models with focus on process industries' specific characteristics is evident.

To serve the purpose, the specific properties of process industries and the way they affect the tactical/S\&OP level are studied. The results have been presented in P1 and in line with RO1. Through this investigation, it has been noticed that the concept of discretization point (DiPo) can be used as a point-of-reference in the design of a planning system which combines the characteristics of both process industries (mainly related to the continuous production) and DIs (discrete production). This idea is further developed in an integrated typology which is presented in $\mathrm{P} 2$ and is in line with RO2. In addition to object type which emphasizes different physical properties of the transformed materials at each side of DiPo, two other flow characteristics are also included in the typology: mode type which refers to the repetitivity of the material flow, and driver type which is related to the trigger of the flow. A modified version of the typology is then applied to S\&OP concept and a differentiated S\&OP process is proposed based on the differentiating characteristics of process industries and DIs in line with RO3 in P3. The relations between different parts of the thesis and the ROs/papers are gathered in Table 6.

Table 6: The relation between the thesis, research objectives and papers

\begin{tabular}{|c|c|c|c|c|}
\hline \multicolumn{2}{|r|}{ Content } & R01/P1 & RO2/P2 & RO3/P3 \\
\hline \multirow{2}{*}{ 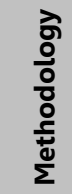 } & 2.4 Theory building & & $\sqrt{ } \sqrt{ }$ & $\sqrt{ } \sqrt{ }$ \\
\hline & 2.5 Literature review & $\checkmark \sqrt{ }$ & $\sqrt{ }$ & $\sqrt{ }$ \\
\hline \multirow{5}{*}{ 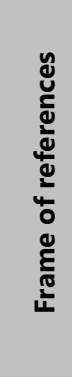 } & 3.1 Process industries & $\sqrt{ } \sqrt{ }$ & $\sqrt{ } \sqrt{ }$ & $\sqrt{ } \sqrt{ }$ \\
\hline & $\begin{array}{l}3.2 \text { Supply chain } \\
\text { management }\end{array}$ & $\sqrt{ } \sqrt{ }$ & $\sqrt{ } \sqrt{ }$ & 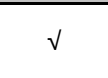 \\
\hline & $\begin{array}{l}\text { 3.3 Planning and control } \\
\text { system design }\end{array}$ & $\checkmark$ & $\sqrt{ } \sqrt{ }$ & $\sqrt{ } \sqrt{ }$ \\
\hline & $\begin{array}{l}\text { 3.4 Manufacturing } \\
\text { planning and control }\end{array}$ & $\sqrt{ } \sqrt{ }$ & $\sqrt{ } \sqrt{ }$ & $\sqrt{ } \sqrt{ }$ \\
\hline & $\begin{array}{l}3.5 \text { Sales and operations } \\
\text { planning }\end{array}$ & $\sqrt{ } \sqrt{ }$ & & $\sqrt{ } \sqrt{ }$ \\
\hline
\end{tabular}


As the result of this study, it has been found that e.g. constrained capacity planning of the inventory and the production, energy provision and use, maintenance plan integration, and variable yield should be considered in the design/implementation of S\&OP process for process industries due to their specific characteristics related to continuous object type. Regarding the mode type, the most influencing factor is set-up time between successive batches/campaigns. This issue is specifically important for process industries due to usually long set-up/cleaning time with sequence-dependent nature. Concerning the driver type, feasibility issues about the cost of low utilization of equipment in the customer order driven part and the possibility of decoupling the production process should be taken into account.

The practical implication of this thesis is mainly about its focus on process industries' properties and the way they affect the planning and control issues of these companies, specifically in relation to S\&OP. Based on the flow characteristics, a typology have been suggested which provides a new insight into classifying process industries and distinguishing them from Dls. From this perspective, Dls can be considered as a special case when the DiPo is located in the beginning of the production process. The typology is then applied to S\&OP process in order to provide a differentiated S\&OP framework for process industries. In practice, the typology and the S\&OP framework can help process industries to classify themselves based on their flow characteristics and select the corresponding planning processes. Specifically, an implementation guide for the suggested S\&OP framework has been outlined.

During this work, several areas have been identified for further investigations as well. First of all, it is important to implement the introduced typology and S\&OP framework in this thesis in the process industries and verify the typology and the framework based on the empirical results. The implementation might result in further refinement and improvement of the proposed typology and S\&OP framework. It can also help in quantifying the results of the implementation in terms of different KPIs e.g. profitability and cash conversion cycle. Another issue regarding the metrics is to find the KPIs related to the specific characteristics of process industries and to categorize them based on the suggested typology. Mixing this approach with the concept of hierarchical planning can lead to a hierarchy of KPIs where each KPI at lower level is connected, and so affects, the KPIs at the higher levels. Another approach, which is in line with using S\&OP as a tool for integration, is to apply the typology and the S\&OP framework to the supply chain context and focus on the relations between different partners rather than specific activities within a company. Thus, the transition points would be integrated into the supply chain management models.

In relation to the role of S\&OP in the supply chain integration and dealing with new trends such as globalization, new areas have been included in this process. Some examples are the integration of supply chain partners, financial planning, new product introduction, and risk/scenario management. Nonetheless, how these issues should be implemented in real world has not been thoroughly dealt with in the academia. In addition, since process industries are usually classified as energy-intensive (Taylor, et al., 1981), the integration of green supply chain topics (Arnold, et al., 1998) such as sustainability (mainly environmental issues), reverse logistics, and energy provision and transformation in tactical planning/S\&OP can help these companies to improve their profitability as well as "greenness". One interesting subject in relation to the sustainability is about the effect of product life cycle on $\mathrm{S} \& \mathrm{OP}$ in general and in relation to process industries in particular. The S\&OP literature has 
not dug into this issue despite the fact that fierce competition has led to shorter product life cycles (Shah, 2005) (lyengar \& Gupta, 2013). Due to the fact that various supply strategies, order winners and qualifiers might be suitable for different life cycle stages; this issue affects the implementation of S\&OP as well as the suitable KPIs (Aitken, et al., 2003). 



\section{Acknowledgement}

The research is performed within the Process Industry Centre (PIC) supported by the Swedish Foundation for Strategic Research (SSF). 



\section{Bibliography}

Abdulmalek, F. A. \& Rajgopal, J., 2007. Analyzing the benefits of lean manufacturing and value stream mapping via simulation: A process sector case study. International Journal of Production Economics, 107(1), p. 223-236.

Abdulmalek, F. A., Rajgopal, J. \& Needy, K. L., 2006. A classification scheme for the process industry to guide the implementation of lean. Engineering Management Journal, 18(2), pp. 15-25.

Aberdeen Group, 2012. Understanding the challenges of today's chief supply chain officers. [Online]

Available at: http://www.aberdeen.com/ [Accessed 2014].

Affonso, R., Marcotte, F. \& Grabot, B., 2008. Sales and operations planning: the supply chain pillar. Production Planning \& Control, 19(2), pp. 132-141.

Aitken, J., Childerhouse, P. \& Towill, D., 2003. The impact of product life cycle on supply chain strategy. International Journal of Production Economics, 85(2), pp. 127-140.

Akkerman, R., Van der Meer, D. \& Van Donk, D. P., 2010. Make to stock and mix to order: choosing intermediate products in the food-processing industry. International Journal of Production Research, 48(12), pp. 3475-3492.

Alexander, D., 2013. S\&OP and strategy: Building the bridge and making the process stick. Journal of Business Forecasting, Spring, pp. 16-19.

APICS, 2011. How to be an S\&OP champion, Chicago: APICS.

APICS, 2012. APICS 2012 big data insight and innovation, Chicago: APICS.

Arnold, J. R. T., Chapman, S. N. \& Clive, L. M., 1998. Introduction to materials management. 7th ed. Upper saddle river, NJ: Prentice Hall.

Ashayeri, J., Teelen, A. \& Selen, W., 1996. A production and maintenance planning model for the process industry. International Journal of Production Research, 34(12), pp. 3311-3326.

Atkinson, W., 2009. S\&OP: Now more than ever. Supply Chain Management Review, September, pp. 50-53.

Basu, R. \& Wright, J. N., 2008. Total supply chain management. 1st ed. UK: Elsevier.

Billesbach, T. J., 1994. Applying lean production principles to a process facility. Production and Inventory Management Journal, 35(3), pp. 40-44.

Blackstone Jr., J. H., 2010. APICS Dictionary. 13th ed. Chicago: APICS.

Bryman, A. \& Bell, E., 2007. Business research methods. 2nd ed. New York: Oxford University Press Inc.

Caux, C., David, F. \& Pierreval, H., 2006. Implementation of delayed differentiation in batch process industries: a standardization problem. International Journal of Production Research, 44(16), p. 3243-3255.

Cecere, L., 2005. Three principles for sound S\&OP. Supply Chain Management Review, May/June, pp. 15-16.

Chae, B., 2009. Developing key performance indicators for supply chain: an industry perspective. Supply Chain Management: An International Journal, 14(6), pp. 422-428.

Childerhouse, P., Aitken, J. \& Towill, D. R., 2002. Analysis and design of focused demand chains. Journal of Operations Management, 20(6), pp. 675-689.

Christopher, M. \& Holweg, M., 2011. "Supply Chain 2.0": managing supply chains in the era of turbulence. International Journal of Physical Distribution \& Logistics Management, 41(1), pp. 63-82. 
Croom, S., 2009. Introduction to research methodology in operations management. In: C. Karlsson, ed. Researching operations management. New York: Routledge, pp. 42-83.

CSCMP, 2014. Council of Supply Chain Management Professionals. [Online] Available at: http://cscmp.org/about-us/supply-chain-management-definitions [Accessed 2014].

Davis, T. S. \& Novack, R. A., 2012. Why metrics, Massachusetts: Supply chain management review.

Dennis, D. \& Meredith, J., 2000a. An empirical analysis of process industry transformation systems. Management Science, 46(8), pp. 1085-1099.

Dennis, D. R. \& Meredith, J. R., 2000b. An analysis of process industry production and inventory management systems. Journal of Operations Management, 18(6), pp. 683-699.

Feng, P., Zhang, J., Wu, Z. \& Yu, D., 2011. An improved production planning method for process industries. International Journal of Production Research, 49(14), pp. 4223-4243.

Feng, Y., D'Amours, S. \& Beauregard, R., 2008. The value of sales and operations planning in oriented strand board industry with make-to-order manufacturing system: Cross functional integration under deterministic demand and spot market recourse. International Journal of Production Economics, 115(1), pp. 189-209.

Finch, B. J. \& Cox, J. F., 1988. Process-oriented production planning and control: Factors that influence system design. The Academy of Management Journal, 31(1), pp. 123-153.

Finch, B. J. \& Luebbe, R. L., 1995. Operations management: Competing in a changing environment. Orlando: Harcourt Brace \& Company.

Fisher, M. L., 1997. What is the right supply chain for your product?. Harvard Business Review, 75(2), pp. 105-117.

Fleischmann, B., Meyr, H. \& Wagner, M., 2008. Advanced planning. In: H. Stadtler \& C. Kilger, eds. Supply chain management and advanced planning: Concepts, Models, Software, and Case Studies. Berlin: Springer, pp. 81-106.

Fransoo, J. C., 1993. Demand management and production control in process industries. International Journal of Operations \& Production Management, 12(7), pp. 187-196.

Fransoo, J. C. \& Rutten, W. G., 1994. A typology of production control situations in process industries. International Journal of Operations \& Production Management, 14(12), pp. 47-57.

Gianesi, I. G., 1998. Implementing manufacturing strategy through strategic production planning. International Journal of Operations \& Production Management, 18(13), pp. $286-$ 299.

Giesberts, P. M. \& Van Der Tang, L., 1992. Dynamics of the customer order decoupling point: impact on information systems for production control. Production Planning \& Control, 3(3), pp. 300-313.

Godsell, J. et al., 2011. Enabling supply chain segmentation through demand profiling. International Journal of Physical Distribution \& Logistics Management, 41(3), pp. 296-314.

Gorry, G. A. \& Morton, M. S. S., 1971. A framework for management information systems. Sloan Management Review, October, pp. 55-70.

Grimson, J. A. \& Pyke, D. F., 2007. Sales and operations planning: An exploratory study and framework. The International Journal of Logistics Management, 18(13), pp. 322-346.

Grossmann, I., 2005. Enterprise-wide optimization: A new frontier in process systems engineering. American Institute of Chemical Engineers, 51(7), pp. 1846-1857.

Hahn, G. J. \& Kuhn, H., 2012. Simultaneous investment, operations, and financial planning in supply chains: A value-based optimization approach. International Journal of Production Economics, 140(2), pp. 559-569. 
Hax, A. C. \& Meal, H. C., 1975. Hierarchical integration of production planning and scheduling. In: M. A. Geisler, ed. Logistics: Volume 1 of North-Holland/TIMS Studies in the Management Sciences. New York: North-Holland Publishing Company, pp. 53-69.

Hayes, R. H. \& Wheelwright, S. C., 1979b. The dynamics of process-product life cycles. Harvard Business Review, 57(2), pp. 127-136.

Hayes, S. \& Wheelwright, R., 1979a. Link manufacturing process and product life cycles. Harvard Business Review, 57(1), pp. 133-265.

Hoekstra, S. \& Romme, J., 1992. Integral logistic structures: Developing customer-oriented goods flow. London: McGraw-Hill.

Holt, C. C., Modigliani, F. \& Simon, H. A., 1955. A linear decision rule for production and employment scheduling. Management Science, 2(1), pp. 1-30.

IVA, 2006. IVA. [Online]

Available at:

http://www.iva.se/upload/Verksamhet/Projekt/Process/IVA\%20M\%20Processind.pdf [Accessed 04 2014].

Ivert, L. K. \& Jonsson, P., 2010. The potential benefits of advanced planning and scheduling systems in sales and operations planning. Industrial Management \& Data Systems, 110(5), pp. 659-681.

lyengar, C. \& Gupta, S., 2013. Building blocks for successful S\&OP. Supply Chain Management Review, November, pp. 10-17.

Jacobs, F. R., Berry, W. L., Whybark, D. C. \& Vollmann, T. E., 2011. Manufacturing planning and control for supply chain management. APICS/CPIM certification ed. United States: Mc Graw Hill.

Jonsson, P., 2011. A sales and operations planning configuration framework. Cambridge, Proceedings of the 2011 EurOMA conference.

Jonsson, P. \& Mattsson, S. A., 2009. Manufacturing, planning and control. Glasgow: McGraw-Hill. Kallrath, J., 2002. Planning and scheduling in the process industry. OR Spectrum, 24(3), p. 219250.

Karlsson, C., 2009. Researching operations management. In: C. Karlsson, ed. Researching operations management. New York: Routledge, pp. 6-41.

Kilic, O. A., Akkerman, R., Van Donk, D. P. \& Grunow, M., 2013. Intermediate product selection and blending in the food processing industry. International Journal of Production Research, 51(1), pp. 26-42.

Klappich, C. D., 2012. A strategic shift. Supply Chain Quarterly, December.

Kopanos, G. M., Puigjanera, L. \& Georgiadisb, M. C., 2011. Resource-constrained production planning in semicontinuous food industries. Computers and Chemical Engineering, 35(12), pp. 2929-2944.

Kovács, G. \& Spens, K. M., 2005. Abductive reasoning in logistics research. International Journal of Physical Distribution \& Logistics Management, 35(2), pp. 132-144.

Lapide, L., 2005. Sales Operations planning part III: A diagnostic model. The Journal of Business Forecasting, 24(1), pp. 13-16.

Lapide, L., 2009. The S\&OP rudder. Supply Chain Management Review, March, pp. 4-5.

Lim, L. L., Alpan, G. \& Penz, B., 2014. Reconciling sales and operations management with distant suppliers in the automotive industry: A simulation approach. International Journal of Production Economics, Volume 151, p. 20-36.

Ling, R. C. \& Goddard, W. E., 1988. Orchestrating success: Improve control of the business with sales \& operations planning. New York: Oliver Wight Limited Publications. 
Little, D., Kenworthy, J., Jarvis, P. \& Porter, K., 1995. Scheduling across the supply chain. Logistics Information Management, 8(1), pp. 42-48.

Lyons, A. C., Vidamour, K., Jain, R. \& Sutherland, M., 2011. Developing an understanding of lean thinking in process industries. Production Planning \& Control, pp. 1-20.

Maccarthy, B. L. \& Fernandes, F. C. F., 2000. A multi-dimensional classification of production systems for the design and selection of production planning and control systems. Production Planning \& Control, 11(5), pp. 481-496.

Maskell, B. H. \& Baggaley, B., 2004. Practical lean accounting: A proven system for measuring and managing the lean enterprise, New York: Productivity press.

Mason-Jones, R., Naylor, B. \& Towill, D. R., 2000. Engineering the leagile supply chain. International Journal of Agile Management Systems, 2(1), pp. 54-61.

McIntosh, R. I., Matthews, J., Mullineux, G. \& Medland, A. J., 2010. Late customisation: issues of mass customisation in the food industry. International Journal of Production Research, 48(6), pp. 1557-1574.

Meredith, J., 1993. Theory building through conceptual methods. International Journal of Operations \& Production Management, 13(5), pp. 3-11.

Meredith, J. R., 2001. Reconsidering the Philosophical Basis of OR/MS. Operations Research, 49(3), pp. 325-333.

Muzumdar, M. \& Fontanella, J., 2006. The secrets to S\&OP success. Supply Chain Management Review, April, pp. 34-41.

Muzumdar, M. \& Viswanathan, N., 2009. Integrated business planning: Kicking S\&OP up a notch. Supply Chain Management Review, October, pp. 34-41.

Noroozi, S. \& Wikner, J., 2013. Sales and operations planning in the process industry. Dublin, 20th International Annual EurOMA Conference.

Noroozi, S. \& Wikner, J., 2014. Sales and operations planning in process industries based on types of object, mode and driver. Innsbruck, 18th International Working Seminar on Production Economics.

Olhager, J., 2003. Strategic positioning of the order penetration point. International journal of Production Economics, 85(3), pp. 319-329.

Olhager, J., 2013. Evolution of operations planning and control: from production to supply chains. International Journal of Production Research, 51(23-24), pp. 6836-6843.

Olhager, J. \& Rudberg, M., 2002. Linking manufacturing strategy decisions on process choice with manufacturing planning and control systems. International Journal of Production Research, 40(10), pp. 2335-2351.

Olhager, J., Rudberg, M. \& Wikner, J., 2001. Long-term capacity management: Linking the perspectives from manufacturing strategy and sales and operations planning. International Journal of Production Economics, Volume 69, pp. 215-225.

Olhager, J. \& Selldin, E., 2007. Manufacturing planning and control approaches: market alignment and. International Journal of Production Research, 45(6), pp. 1469-1484.

Oliva, R. \& Watson, N., 2011. Cross-functional alignment in supply chain planning: A case study of sales and and operations planning. Journal of Operations Management, 29(5), pp. 434-448.

Pagh, J. D. \& Cooper, M. C., 1998. Supply chain postponement and speculation strategies: how to choose the right strategy. Journal of Business Logistics, 19(2), pp. 13-34.

Papageorgiou, L. G., 2009. Supply chain optimisation for the process industries: Advances and opportunities. Computers and Chemical Engineering, Volume 33, pp. 1931-1938.

Pool, A., Wijngaard, J. \& van der Zee, D.-J., 2011. Lean planning in the semi-process industry, a case study. International Journal of Production Economics, Volume 131, pp. 194-203. 
Prokopets, L., 2012. S\&OP: What you can learn from the top performers. Supply Chain Management Review, May/June, pp. 28-35.

Proud, J. F., 1999. Master scheduling: A practical guide to competitive manufacturing. 2nd ed. US: John Wiley \& Sons.

Rowley, J. \& Slack, F., 2004. Conducting a Literature Review. Management Research News, 27(6), pp. 31-39.

Sabri, E. \& Shaikh, S., 2013. Lean and agile: Acheiving peak levels of sales and operations planning. APICS Magazine, Sep/Oct, pp. 43-45.

Shah, N., 2005. Process industry supply chains: Advances and challenges. Computers and Chemical Engineering, 29(6), p. 1225-1236.

Shah, N. K. \& lerapetritou, M. G., 2012. Integrated production planning and scheduling optimization of multisite, multiproduct process industry. Computer and Chemical Engineering, Volume 37, pp. 214-226.

Sharda, B. \& Akiya, N., 2012. Selecting make-to-stock and postponement policies for different products in a chemical plant: A case study using discrete event simulation. International Journal of Production Economics, 136(1), pp. 161-171.

Sharman, G., 1984. The rediscovery of logistics. Harvard Business Review, 62(5), pp. 71-79.

Shobrys, D. E. \& White, D. C., 2002. Planning, scheduling and control systems: Why cannot they work together. Computers and Chemical Engineering, 26(2), pp. 149-160.

Singhal, J. \& Singhal, K., 2007. Holt, Modigliani, Muth, and Simon's work and its role in the renaissance and evolution of operations management. Journal of Operations Management, 25(2), pp. 300-309.

Singh, M. K., 2010. What makes a winning S\&OP. Supply Chain Management Review, May/June, pp. 22-27.

Soman, C. A., van Donk, D. P. \& Gaalman, G., 2004. Combined make-to-order and make-to-stock in a food production system. International Journal of Production Economics, 90(2), p. 223235.

Stadtler, H., 2008. Supply chain management - An overview. In: H. Stadtler \& C. Kilger, eds. Supply chain management and advanced planning: Concepts, Models, Software, and case studies. Berlin: Springer, pp. 9-36.

Stiftelsen för Strategisk Forskning, 2007. Stiftelsen för Strategisk Forskning. [Online] Available at: http://www.stratresearch.se/global/utlysning pdf/PC06 sw.pdf [Accessed 04 2014].

Taylor, S. G. \& Bolander, S. F., 1994. Process flow scheduling: A scheduling systems framework for flow manufacturing. Virginia : American Production and Inventory Control Society (APICS).

Taylor, S. G., Seward, S. M. \& Bolander, S. F., 1981. Why the process industries are different. Production and Inventory Management, Fourth quarter, pp. 9-24.

Thome, A. M. T., Scavarda, L. F., Fernandez, N. S. \& Scavarda, A. J., 2012a. Sales and operations planning: A research synthesis. International Journal of Production Economics, Volume 138, pp. 1-13.

Thome, A. M. T., Scavarda, L. F., Fernandez, N. S. \& Scavarda, A. J., 2012b. Sales and operations planning and the firm performance. International Journal of Productivity and Performance Management, 61(4), pp. 359-381.

Towill, D. R., 2005. Decoupling for supply chain competitiveness. IEE Manufacturing Engineer, 84(1), pp. 36-39. 
Tranfield, D., Denyer, D. \& Smart, P., 2003. Towards a methodology for developing evidenceinformed management knowledge by means of systematic review. British Journal of Management, 14(3), pp. 207-222.

Wacker, J. G., 1998. A definition of theory: research guidelines for different theory-building research methods in operations management. Journal of Operations Management, 16(4), pp. 361-385.

Wacker, J. G., 2004. A theory of formal conceptual definitions: developing theory-building measurement instruments. Journal of Operations Management, 22(6), pp. 629-650.

Wacker, J. G., 2008. A conceptual understanding of requirements for theory-building research: Guidelines for scientific theory building. Journal of Supply Chain Management, 44(3), pp. 515.

Wallace, T., 2006. Forecasting and sales \& operations planning: Synergy in action. The Journal of Business Forecasting, Spring, pp. 16-21.

Wallace, T. F., 1999. Sales \& Operations Planning: The how-to handbook. 1st ed. Ohio: T. F. Wallace \& Company.

Wallace, T. F. \& Stahl, R. A., 2008. Sales and operation planning: The how-to handbook. 3rd ed. s.l.:T. F. Wallace and company.

Waller, D. L., 1999. Operations management: $A$ supply chain approach. London: International Thomson Business Press.

van der Zee, D. J., Pool, A. \& Wijngaard, J., 2008. Lean engineering for planning systems redesign: Staff participation by simulation. Miami, Proceedings of the 2008 Winter Simulation Conference.

Van Donk, D. P., 2001. Make to stock or make to order: The decoupling point in the food processing industries. International Journal of Production Economics, 69(3), pp. 297-306.

Van Donk, D. P. \& Fransoo, J. C., 2006. Operations management research in process industries. Journal of Operations Management, 24(3), pp. 211-214.

van Donk, D. P. \& van der Vaart, T., 2005. A case of shared resources, uncertainty and supply chain integration in the process industry. International Journal of Production Economics, 96(1), pp. 97-108.

Van Hoek, R., 2001. The rediscovery of postponement a literature review and directions for research. Journal of Operations Management, 19(2), pp. 161-184.

Van Hoek, R. I., 1999. Postponement and the reconfiguration challenge for food supply chains. Supply Chain Management: An International Journal, 4(1), pp. 18-34.

Weick, K. E., 1995. What theory is not, theorizing is. Administrative Science Quarterly, 40(3), pp. 385-390.

Wight, O. W., 1984. MRP II: Unlocking America's productivity potential. Vermont: Oliver Wight Limited Publications.

Wikner, J., 2014. On decoupling points and decoupling zones. Production \& Manufacturing Research, 2(1), pp. 167-215.

Wikner, J. \& Noroozi, S., 2014. Typology for planning and control - Combining object type, mode type, and driver type. Cardiff, SDM.

Wikner, J. \& Rudberg, M., 2005. Introducing a customer order decoupling zone in logistics decision-making. International Journal of Logistics: Research and Applications, 8(3), p. 211224.

Viswanathan, N., 2011. Sales and operations planning: Key enabler for the chief supply chain officers, Boston: Aberdeen Group. 
Woodward, J., 1965. Industrial organization: Theory and practice. 2nd ed. London: Oxford University Press.

Yin, R. K., 2009. Case study research: Design and methods. 5 ed. California: Sage Inc. 

Appended papers 



\section{Papers}

The articles associated with this thesis have been removed for copyright reasons. For more details about these see:

http://urn.kb.se/resolve?urn=urn:nbn:se:liu:diva-106709 